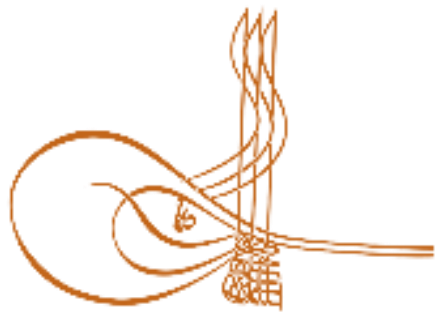

www.turkishstudies.net/social
Turkish Studies - Social Sciences

eISSN: $2667-5617$

Research Article / Araşttrma Makalesi

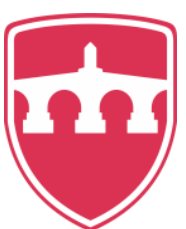

INTERNATIONAL

BALKAN

UNIVERSITY

Sponsored by IBU

\title{
Maymun Dağı(Çardak-Denizli/Dazkırı-Afyonkarahisar)'nın Morfotektonik Özelliklerinin CBS ile Belirlenmesi
}

\author{
Determination of Morphotectonic Features of the Maymun Mountain (Çardak-Denizli/Dazkiri- \\ Afyonkarahisar) Using by GIS
}

\author{
İsmail Ege* - Neşe Duman ${ }^{* *}$
}

\begin{abstract}
Aegean Region has many horst graben systems due to the effects of extensional tectonic regime. Graben fields generally correspond to the plains, while horsts match to mountainous masses. It is possible to observe the traces of active tectonics in the Aegean region where formation processes are active and to reveal them with quantitative data. Supporting geomorphological features clearly observed with good field experience with digital data, quantitative determination of tectonic development carried geomorphology studies to a different dimension with Geographical Information Systems (GIS) technolog. In this study, the geomorphological features of the Maymun Mountain horst forming the northern part of the Acıgöl graben section of Büyük Menderes graben were tried to be determined by morphometric analysis. Although it is not clear from which points the separation of the border between Beşparmak Horst and Maymun Mountain will be made, this study is based on the characteristic basins located on the north-northwest and south parts of the mountain. It corresponds to an area of $282 \mathrm{~km}^{2}$. In this study, the geomorphological characteristics of the Maymun Mountain, which arose as a result of geological structure, tectonism and other factors and processes in this area, have been tried to be determined by quantitative data. In this study, the geomorphological characteristics of the Maymun Mountain, which is the result of the geological structure, tectonism and other factors and processes in this area, has been tried to be determined by quantitative data. In this study, geomorphometric indices; hipsometric curve $(\mathrm{Hc})$ - hipsometric integral (Hi), valley floor width - valley height ratio (Vf), valley width, triangular surface (facet) index (Pf), mountain front sine ratio (Smf) ) calculated; geomorphological development of the basin. In this study, $5 \mathrm{~m}$ resolution Digital Height Model (DEM), geology data, active fault data and GIS software ArcGIS10.5 package program were used. After the study, the formation of Maymun Mountain, its geomorphological development and morphometric properties were revealed.
\end{abstract}

\footnotetext{
* Dr. Öğr. Üyesi, Uşak Üniversitesi, Fen-Edebiyat Fakültesi, Coğrafya Bölümü Asst. Prof. Dr., Usak University, Faculty of Arts and Sciences, Geography Department ORCID 0000-0001-5896-0440

ismailege01@gmail.com

** Dr. Öğr. Üyesi, Karatekin Üniversitesi Fen-Edebiyat Fakültesi, Coğrafya Bölümü

Asst. Prof. Dr., Karatekin University, Faculty of Arts and Sciences, Geography Department

ORCID 0000-0002-5398-8388

mail adresi: neseduman@karatekin.edu.tr

Cite as/ Atıf: Ege, İ., Duman, N. (2020). Maymun Dağı (Çardak-Denizli/Dazkır1-Afyonkarahisar)'nın morfotektonik özelliklerinin CBS ile belirlenmesi, Turkish Studies - Social, 15(1), 277-307.
} https://dx.doi.org/10.29228/TurkishStudies.39211

Received/Geliş: 10 October/Ekim 2019

Accepted/Kabul: 25 February/Şubat 2020

Copyright $(\mathrm{C}$ INTAC LTD, Turkey 
Structured Abstract: Aegean Region has many horst graben systems due to the effects of extensional tectonic regime. Graben fields generally correspond to the plains, while horsts correspond to mountainous masses. It is possible to observe the traces of active tectonics in the Aegean region where formation processes are active and to reveal them with quantitative data. Nowadays, Geomorphology studies with Geographic Information Systems (GIS) technology takes different dimension especially geomorphological features supported by a good field experience, supporting the geomorphological features, quantitative analysis of tectonic development. Quantitative data is obtained from the analysis of morphometric properties used in geomorphology can be better interpreted by the factors involved in the embodiment and development of basins (Özdemir 2007).

In this study, the geomorphological features of the Maymun Mountain, located between Acıgöl graben and the Baklan graben in the esat section of Büyük Menderes Graben, which has a very young landscape, has been tried to be determined by morphometric analysis. The research area corresponds to the Maymun mountain with an area of approximately $282 \mathrm{~km}^{2}$.

In the study, geomorphometric indices; hypsometric curve - hypsometric integral (Hi), valley width, triangular surface (bezel) index (Pf), mountain front sinusoid ratio (Smf), basin asymmetries (Dd) calculated and have explained to Geomorphological development of the Maymun mountain.

In the study, Different materials and software were used $5 \mathrm{~m}$ resolution Digital Elevation Model (DEM), geology data, active fault data and ArcGIS10.5 software from GIS software. After the study, it was revealed that the faults on the formation and formation of the basin, tectonism was very active and it was a very young basin.

Firstly, Maymun mountain was divided to basins. Then, Hypsometric curve and Integral were calculated with supporting ArcGIS. According to Analaysis; Hypsometric Integral of Basins on the Maymun mountain is 0,49. This ratio is relatively low for Mountain. This stiuation is related to lithology which is conglomerate. Dendritic Drainage type is appeared in study area. Beginning of streams is partly hooked Drainage. This situation occurred due to the faulting in the field. It is clear that there is a close relationship between fault lines and hooked drainage. Faults that shape the Maymun mountain have also guided the rivers.

Mountain Front Sinusity Ratio (Smf) is calculated from four different parts of the Maymun Mountain. Accordingly, in the south of the mountain (around Çardak) and southeast, Smf values are aproxmitly 1.2 the most severe and the newest tectonic activity. In the part of north where it is direction of from NW to SE Smf value is 3,35 which is very higher than other parts. In this indicated that tectonic activity is very slow in this area and fluvial process is dominate than other prosses.

Another index applied in the research area is the Valley Floor Width to Valley Height Ratio (Vf) index. If the valleys where Vf values are less than 1 are generally classified as V-shaped valleys, there are active deep erosion of the stream associated with rapid tectonic elevation in the present. Vf values between 1 and 1.5 indicate moderately active tectonics. Vf values greater than 1.5 are classified as U-shaped valleys exposed to large lateral erosion. In Maymun Mountain is analyzed at different Points. These; upper part of mountain is 0,95 ; middle part of basins is 0,95 and groundbreaking down basins is 3,13 . There is a misfortune in here. When we look at the mean Vf values, we see that in the high uplands of the Maymun Mountain, 0.95 is found in the upstream caverns of the basins and much lower than 0.45 in the middle ground. This can be said that there are tectonic rejuvenations on the Maymun Mountain and the site is in the youth stage. All these values indicate active tectonics in the Maymun Mountain.

Another analysis to understand the impact of tectonism in basins is the basin asymmetry. Here; As the result is close to 0 , the basin is symmetrical and as close to 1 it is asymmetric. According to the analysis of the asymmetric status of the Maymun Mountain; A high value of 0.97 is observed in the Dutluca basin, 0.76 in the Kurudere basin, 0,67 in the Kösüklerdere basin and 0.62 in the Hapisdere basin in the upstream respectively. Here, the T (Topographic Symmetry) values are very close to 1 this shows that the tectonism in the Maymun Mountain is very high.

In geomorphology studies, there are podgy hills which are triangle surface with flats showing the effect of tectonism in the transition from plain areas to mountainous areas. The existence of tectonism and the degree of split of the valleys between the triangle hills and the presence of active tectonics according to the deformation of the deposit cones are evaluated. There are very characteristic triangle hills at the south and southeast part of 
Maymun Mountain. In these area there are very high triangle hills and very small alluvial fans between hills front of mountain. Elevations behind of triangle hills also indicate that faulting is in several stages.

Finally, the topography features which are shaped with geomorphological processes give information about active faulting and the structure of tectonism in the mountainously areas. The percentage of places where the degree of slope is close to zero is mostly older, and the percentage where the degree of slope is close to 90 is higher, whereas the higher percentage is the younger. In the Özdemirci Basin, the percentage of places with a slope between $0-1$ is only $1,1 \%$ and the sloping flats in the slope $1-3$ are $17,27 \%$. The areas other than this have a ratio of $82 \%$ as sloped, sloping, very sloping and steep terrain. This also shows that the Maymun Mountain is a newly formed young mountain.

As a result, Tilting faults have an effective role in the embodiment of the basin, which consists mainly of the Upper Oligocene and Miocene conglomerates. Particularly the front of mountain were timely formed over the young faults. Maymun Mountain is a relatively young mount that has begun to form at the end of Pliocene - Quaternary and its formation is still in progress. Traces of tectonism in the field are selected very clearly. The embodiment has the same characteristics as the tectonism of the Aegean region.

Keywords: Tectonic Geomorphology, Maymun Mountain, Basins, Morphometric Analysis, GIS.

Öz: Ege Bölgesi, genişlemeli tektonik rejimin etkisi ile birçok horst graben sistemine sahiptir. Graben sahaları genellikle ovalara karşılık gelirken, horstlar dağlık kütlelere karşılık gelmektedir. Oluşum süreçlerinin devam ettiği Ege bölgesinde aktif tektoniğin izlerini belirgin olarak gözlemlemek ve kantitatif verilerle ortaya koymak mümkündür. Arazi çalışmaları ile net olarak gözlemlenen jeomorfolojik özelliklerin sayısal verilerle desteklenmesi, tektonik gelişimin kantitatif olarak ortaya konması jeomorfoloji çalışmalarını Coğrafi Bilgi Sistemleri (CBS) teknolojisi ile farklı bir boyuta taşımıştır. Bu çalışmada Büyük Menderes grabeninin, Acıgöl grabeni bölümünün kuzeyini oluşturan Maymun Dağ1 horstunun jeomorfolojik özellikleri morfometrik analizlerle tespit edilmeye çalışılmıştır. Maymun Dağının Beşparmak horstu ile sınır ayrımının hangi noktalardan yapılacağı çok net olmamakla beraber, bu çalışma da dağ üzerinde kuzey-kuzeybatı ve güney kısımda yer alan karakteristik havzalar esas alınarak Beşparmak dağının güney yamaçları da havzaya dahil edilerek bir sınır oluşturulmuştur. Araştırma alanı yaklaşık olarak $282 \mathrm{~km}^{2}$ lik bir sahaya karşılık gelmektedir. $\mathrm{Bu}$ çalışma ile bu alanda jeolojik yapı, tektonizma, diğer etken ve süreçlerin işlemesi sonucu ortaya çıkan Maymun Dağının jeomorfolojik özellikleri kantitatif verilerle ortaya konulmaya çalışılmıştır. Dağın üzerinde bulunan, Kuruçay deresi, Koca dere, Tokat deresi, Acıpınar deresi, Çardak kuzeyindeki Göz deresi, Batıda Dutluca deresi, kuzeybatıda Yeşilgöldere havzaları morfometrik olarak analiz edilmiştir. Çalışmada bu havzalarda jeomorfometrik indislerden; hipsometrik eğri (He) - hipsometrik integral (Hi), vadi taban genişliği - vadi yüksekliği oranı (Vf), vadi genişliği, üçgen yüzey (feçeta) indeksi (Pf), dağ önü sinüslük oranı (Smf) hesaplanmış; havzanın morfometrik özellikleri jeomorfolojik gelişimi ortaya konulmaya çalışılmıştır. Çalışmada araştırma alanının 5 m çözünürlüklü Sayısal Yükseklik Modeli (DEM), jeoloji verisi, aktif fay verisi kullanılmış ve CBS yazılımlarından ArcGIS10.5 paket programı tercih edilmiştir. Çalışma sonrasında Maymun Dağının oluşumu, jeomorfolojik gelişimi ve morfometrik özellikleri ortaya konulmuştur.

Anahtar Kelimeler: Tektonik jeomorfoloji, Maymun Dağı, havzalar, morfometrik analizler, CBS

\section{Giriş}

Morfometri Çalışmalarının temelleri eskiye dayanmakla beraber, yeni teknolojik gelişmelere bağlı olarak farklı bir ivme kazanmıştır. CBS ve uzaktan algılama alanındaki gelişmeler (yazılımsal ve donanımsal) bunu sağlayan en önemli faktörlerdendir. İlk çalışmalar Strahler (1952); Schuman (1956); Pike ve Wilson (1971); Hack (1973); Harlin (1978); Keller (1986); Western vd. (1997); Mayer (1990); Biswas, Sudhakar \& Desai (1999); Keller ve Pinter (2002); Reddy vd. (2004); Bull (1978; 2007); Demoulin (2011) tarafından yapılmıştır. Ülkemizde morfometri çalışmaları CBS teknolojisinin kullanımı ile paralellik arz etmektedir. Bu çalışmalardan bazıları Turoğlu (1997); Cürebal (2004); Cürebal ve Erginal (2007); Özdemir (2007; 2011); Erginal ve Cürebal (2007); Öztürk ve Erginal (2008); Bahadır ve Özdemir (2011); Sarp vd. (2011); Y1ldırım ve Karadoğan (2011); Karataş (2014); Uzun (2014); Avcı ve Günek (2015); Köle (2016); Topuz ve Karabulut 
(2016); Avcı ve Sunkar (2017); Avcı ve Kıranşan (2017); Geçen ve Ölmez (2017); Fural (2018); Topal (2018); Ege vd. (2019); İzmirli ve Ege (2019); Zorer ve Tonbul (2019) tarafından yapılmıştır.

Jeomorfolojide kullanılan morfometrik özelliklerin analizi sonucu elde edilecek kantitatif verilerle, havzaların oluşum ve gelişmesinde rol oynayan etmenler daha iyi yorumlanabilmektedir (Özdemir, 2007). Bu çalışmada Büyük Menderes Grabeni'nin yukarı çığırını oluşturan Çivril Baklan Grabeni ile güney kesiminde Acıgöl Grabeni arasındaki Maymun Dağının morfometrik özellikleri tektonik jeomorfoloji açısından ortaya konulmaya çalışılmıştır.

\subsection{Maymun Dağının Yeri ve Sınırları}

Genel olarak Ege Bölgesi'nin İç Batı Anadolu Bölümü'nde yer alan Maymun Dağı idari olarak batı kesimi Denizli ili Çardak ve Baklan ilçeleri, doğu kesimi ise Afyonkarahisar ili Dazkırı ilçesi sınırları içerisinde yer almaktadır. İki ilin idari sınırını oluşturan bu dağlık kütle üzerinde büyüklü küçüklü 20'yi aşkın hidrografik havza yer almaktadır. Bu çalışmada bu havzalar sadeleştirilerek 10 havzaya yönelik analizler gerçekleştirilmiştir. Maymun Dağı aynı zamanda Acıgöl grabeni içerisinde bulunan Bozkurt ovası ile Baklan ovası arasında kalan dağlık kütleye karşılık gelmektedir. Maymun Dağı Çardak ilçe merkezi civarında birikinti yelpazelerinin üzerinden doğuya doğru, Acıgöl ile kıyı çizgisi oluşturan sahadan Derbent boğazı civarından kuzeydoğu istikametinden ilerlendiğinde Dazkırı ilçe merkezine, buradan Kuru derenin doğu kesimindeki su bölümü çizgisini takip ederek Gaman gediği mevkiinden Kızılören'e ulaşılır. Kızı̈ören mevkiinden kuzeybatı istikametinde Bakarca tepeye $(1236 \mathrm{~m})$ ulaşılır. Buradan itibaren doğu-batı istikametinden Hizaralan köy yerleşmesinin güneyinde Bozoğlan tepe (1548 m), Deve çukuru mevkiinden Topocağ tepeye ulaşılır. Burası aynı zamanda kuzeybatıda yer alan Beşparmak Dağı'nın en yüksek kesimini oluşturur. Araştırma sahası sınırı Beşparmak Dağı zirvesinden güneybatı istikametinden Beşparmak sırtından Baklan ovasına doğru ilerler ve Yeşilgöldere havzasının sınırlarını takip ederek Armutalanı köyünün batısında Süleyman bağ mevkiinden tamamen güneye yönelerek Kalpaklı tepe (1169,8 m) mevkiinden Dutluca köyü batısından tekrar Çardak ovasına ulaşır. Hem dağlık alanın başladığı iç bükey araziler hem de havzaların su bölümü çizgileri esas alınarak Maymun Dağının sınırları oluşturulmuştur (Şekil 1). 


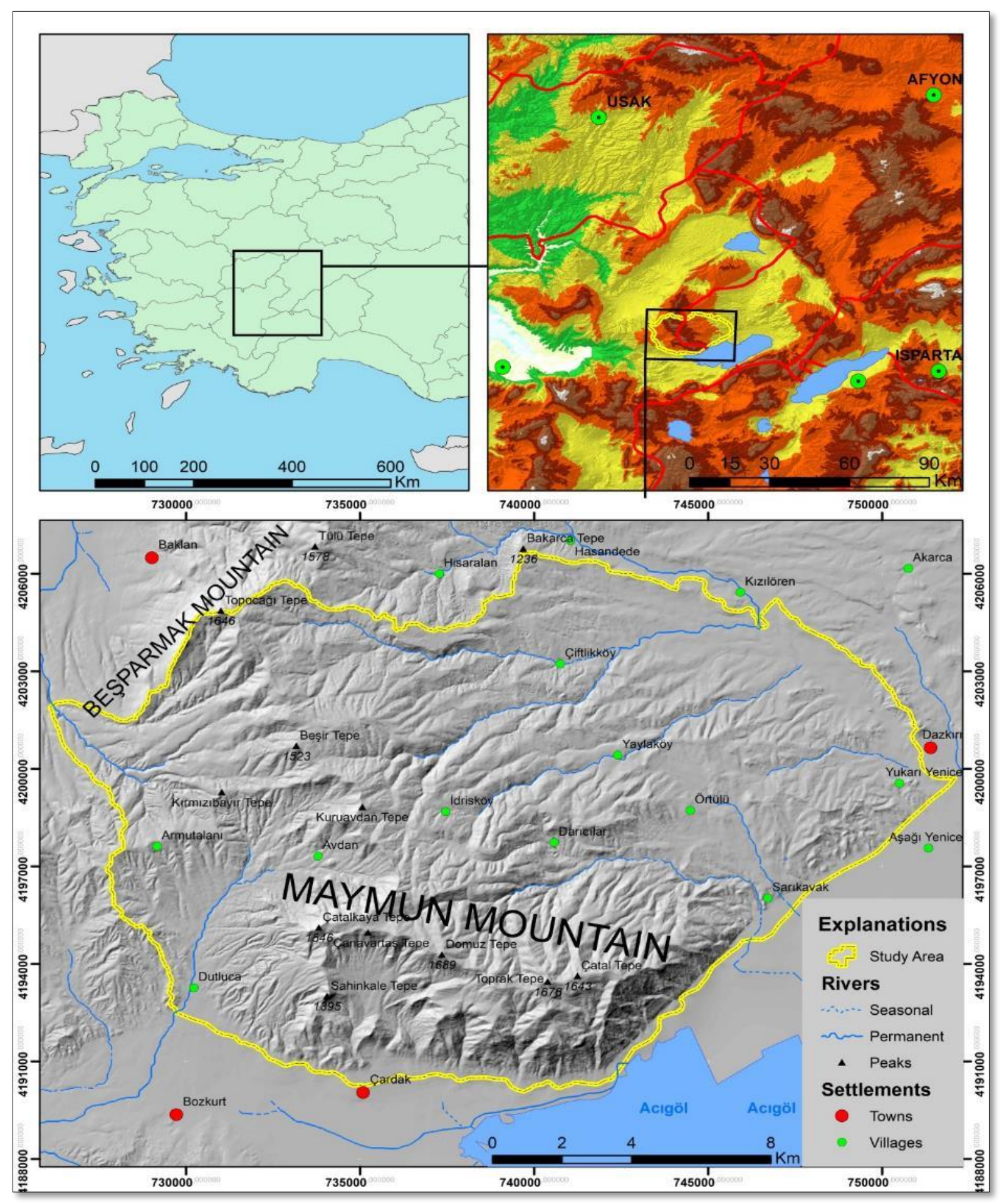

Şekil 1. Maymun Dağının Lokasyon Haritası

\subsection{Amaç}

$\mathrm{Bu}$ çalışmanın amacı Maymun Dağının morfotektonik özelliklerini Coğrafi Bilgi Sistemlerini (CBS) kullanarak ortaya çıkarmaktır. Böylece çalışma sonucunda Maymun Dağının tektonik jeomorfoloji özellikleri belirlenmiş olacaktır. Bu kapsamda dağın, hipsometrik eğri ve 
hipsometrik integral indisi (Hi), vadi tabanı genişliği-vadi yüksekliği oranı (Vf), üçgen yüzey (façeta) indeksi (Pf), dağ önü sinüslük oranı (Smf), eğim ve bakı özellikleri hesaplanarak morfometrik özellikleri ortaya konulacaktır.

\subsection{Yöntem ve Materyal}

Araştırma sahasının morfometrik özelliklerini ortaya koyabilmek için öncelikle hipsometrik eğri $(\mathrm{He})$ ve hipsometrik integral (Hi) hesaplaması yapılmıştır. Tektonik olarak oldukça aktif bir sahaya karşılık gelen bu dağlık kütlenin tüm kesimlerinde faylanma aktivitesi aynı oranda işlemediği için dağın morfometrik özellikleri havzalara ayrılarak hesaplanmıştır. Temelde 10 havza ele alınarak; Hipsometrik eğri ve hipsometrik integral indisleri ayrı ayrı hesaplanmıştır. Bunların dışında havzaların vadi tabanı genişliği-vadi yüksekliği oranı değerleri ve havza asimetrileri de tek tek farklı noktalardan alınarak değerlendirilmiştir. Dağın tektonik gelişimi ve fay yamaçlarındaki derecelendirmeye yönelik olarak dört ayrı kesimde dağönü sinüslük indeksi hesaplaması yapılmıştır. Hipsometrik eğri, toplamdaki havza yüksekliği oranının $(\mathrm{h} / \mathrm{H}=$ rölatif yükseklik) ve toplamdaki havza alanı oranının $(\mathrm{a} / \mathrm{A}=$ rölatif alan) birlikte değerlendirilmesiyle elde edilir. Hipsometrik integral $\left(\mathrm{H}_{\mathrm{i}}\right)$, hipsometrik eğri altında kalan toplam alandır ve çalışılan drenaj havzası için hipsometrik eğriyi karakterize etmenin en basit yoludur (Keller ve Pinter, 2002). İntegrali hesaplamada havzanın maximum, minimum ve ortalama yükseklik değerleri kullanılır (Pike ve Vilson, 1971; Mayer, 1990).

Yapılan bu çalışmada öncelikle sahanın 1/25.000 ölçekli M23a1, M23a2 M23a3, M23a4, M23b1 ve M23b4 kodlu topografya haritaları temin edilmiş ve havzanın eğimli alanlarda $10 \mathrm{~m}$ düze yakın alanlarda $5 \mathrm{~m}$ aralıklarla eş yükselti eğrileri sayısallaştırılmıştır. Bu veriden $5 \mathrm{~m}$ çözünürlükte DEM verisi üretilmiş ve daha sonra bu veriden eğim (slope), bakı (aspect), kabartma (hillshade) haritaları üretilmiştir. Yine DEM'den havza analizine yönelik olarak ArcToolbox, hidroloji kısmından havza (watershed), akarsu dizinleri (stream order) ve havza sinırları (basin) analizleri yapılmıştır. Çalışmada jeomorfolojik gelişimin yorumlanmasına altlık teşkil etmesi için MTA'dan jeoloji ve fay verileri temin edilmiş böylece sahanın $1 / 25.000$ ölçekli jeoloji haritaları çizilmiştir. Tüm verilerin CBS ortamına aktarılmasından sonra analizlere yönelik görseller oluşturulmuştur.

Araştırma alanına yönelik yapılan hesaplamalardan sonra çıkan sonuçların doğruluk dereceleri, sahanın jeomorfolojik özellik ve gelişimini yerinde analiz etmek için farklı tarihlerde arazi çalışmaları yapılmıştır. Araziden toplanan numuneler ve alınan fotoğraflar ile birlikte çalışma metni oluşturulmuştur.

\subsection{Jeolojik ve Fiziki Özellikler}

Batı Anadolu, Neotektonik dönem boyunca farklı doğrultularda gelişmiş horst ve graben sistemlerinden oluşmaktadır. Acıgöl grabeni de bu sistemlerinden biri olup, Denizli-Afyon il sınırında, yaklaşık $45 \mathrm{~km}$ uzunluğunda ve $14 \mathrm{~km}$ genişliğinde KD-GB uzanımlı bir grabendir. Havza KB'da Maymundağı fayı, GD'da Acıgöl fayları ile sınırlıdır (Tagliasacchi ve Yağmurlu, 2019). Paleotektonik dönemde GD-KB istikametinde sıkışma, Neotektonik dönemde G-K istikametinde açılma tektoniğinin etkisi ile şekillenmiş olan araştırma sahasında Eosen- Kuvaterner aralığında çok farklı depolanmalar olmuştur. Batı Anadolu'da gelişen Tersiyer havzaları, Neotektonik dönemden önce KD-GB uzanımlı bir tek havza olup, günümüzde aynı hat üzerinde birbirleriyle bağlantıları temel yükseltilerle kesilmiştir. Bu havzalar, bölgenin güneybatısında yeralan Kale-Tavas havzası ile hemen doğusunda yeralan Denizli ve Çardak-Dazkırı havzalarıdır ve doğudan batıya doğru gençleşerek çökelmişlerdir (Sözbilir, 2005).

Grabenin KB'sındaki Maymun Dağı 1689 m (Domuz T.) ve GD'sundaki Yan Dağ'ın yükseltisi 2033m'dir. Graben havzasını sınırlayan Maymun Dağı yükseltisi Oligosen yaşlı Çardak formasyonu ile temsil edilmektedir. Bu birim, başlıca kumtaşı ve çamurtaşı ara düzeyleri içeren çakıltaşlarından oluşmaktadır. Gabenin GD'daki yükselim alanlarında ise bölgeye Kampaniyen'de yerleşen allokton konumlu ofiyolit, ofiyolit karmaşığı ve Mesozoyik karbonatları yüzeylemektedir. 
Bölgede yapılan jeomorfolojik veriler ışığında, graben havzasının GD kenarı boyunca, KB kenarına oranla daha yüksek bir sübsidansin olduğu belirtilmiştir (Price ve Scott, 1994).

Acıgöl Grubuna ait Oligosen tortulları, Acıgöl'ün kuzey kesiminde yüzlek vermekte ve molas karakterinde kalın katmanlı çakıltaşı-kumtaşı ve çamurtaşı bileşenlerinden oluşmaktadır. (Şahbaz ve Görmüş, 1992). Böylece Maymun Dağının hemen hemen bütünü konglomeralardan meydana gelmektedir (Foto 1). Büyük çoğunluğunu Oligosen yaşlı Çardak Formasyonu oluşturmakla beraber, temelde Lütesiyen yaşlı Başçeşme Formasyonu ve bunun dışında özellikle kuzeyde Beşparmak Dağı'nın batı yamaçlarında mostra veren formasyonlarda mevcuttur. Araştırma sahasında en genç formasyonlar Dazkırı çevresinde Pliyosen yaşlı Çameli Formasyonu ve Sarıkavak köyü çevresinde Kuvaterner yaşlı traverten - tufa çökellerine rastlanılmaktadır (Şekil 2).

Maymun Dağı'nı oluşturan formasyonlar Eosen, Oligosen, Pliyosen ve Kuvaterner zamana ait tortullar farklı genişlikte ve derinlikte bir yayılışa sahiptir. Jeolojik olarak Çardak- Dazkırı Havzasına karşılık gelen Maymun Dağı yükseliminde hakim formasyonu Acıgöl grubu olarak bilinen Üst Oligosen (Göktaş ve diğ., 1989) yaşlı tortullar oluşturur. Grup Armutalanı, Çardak, Hayrettin, Çameli ve Başçeşme formasyonu olmak üzere beş formasyona ayrılmıştır. Eosen yaşlı Başçeşme formasyonu ve üzerine uyumsuz olarak gelen Oligosen yaşlı Acıgöl grubu, genellikle karasal ve yer yer sığ denizel ortamlarda depolanmış çökellerdir. Araştırma sahasında birime ait tipik görüntüler Çardak ilçesi'nin kuzeyinde, Mecidiye Köyü ve Avdan Köyü’nün çevresinde yaygın olarak gözlenmektedir. Şenel (1997), Çardak Formasyonu içerisinde alttan üste doğru dört farklı üye ayırt etmiştir. Bu üyeler sırasıyla; Karanlık Üyesi, Kirazlı Üyesi, Avdan Üyesi ve en üstte Maymundağ1 Üyesi olarak ayrılmıştır.

Karanlık Üyesi; Çardak Formasyonunun tabanını oluşturan bu birim genellikle çakıllı kaba taneli, sarımsı kahverengi renginde, orta-kalın tabakalı kumtaşlarından oluşmaktadır. Çalışma alanının çok küçük bir kısmında ve Armutalanı Köyü'nün kuzeydoğusunda gözlenmektedir. Karanlık Üyesinin kalınlığı; 1-10m arasında değişmektedir.

Kirazlı Üyesi; Karanlık Üyesi’nin hemen üzerine gelen bu birim, alttaki birime göre daha geniş bir yayılıma sahiptir. Bu birim, Mecidiye Köyü’nün güneybatısından Çardak ilçesine kadar uzunlamasına gelişen bir hat boyunca gözlenir. Kirazlı üyesi, ince-orta-kalın tabakalı, yeşilimsi gri ve sarımsı kahve renklerindeki çamurtaşı, kumtaşları ve yer yer de çakıltaşlarından oluşmaktadır. Kumtaşlarının üzerinde bol miktarda sürünme ve beslenme gibi iz fosillerine rastlanılmaktadır. Yanal yönde Avdan Üyesine geçiş göstermektedir. Kirazlı Üyesinin kalınlı̆ğ 400-600 metre arasindadır (Toker, 2008).

Avdan Üyesi; genellikle kumtaşı, çamurtaşı ardalanmasından oluşan türbiditik bir yapı gösteren bu birim, özellikle Avdan Köyü’nün çevresinde yaygın olarak gözlemektedir. Avdan üyesinin üst kesimlerine doğru konglomera seviyesinde önemli derecede bir artı̧̧ görülmektedir. Likya Naplarından türemiş serpantinit bileşenleri, çakıltaşları içerisinde yer yer görülmektedir. Çakıltaşları, bazalt ve bozunmuş serpantinitlerden ve kireçtaşlarından türemiştir. Bu durum, Likya Naplarının bu bölgeye daha önce gelip yerleştiğini göstermektedir (Toker, 2008).

Maymundağı Üyesi; Çardak ilçesinin hemen kuzeyinden başlayarak çalışma alanının büyük bir kısmını oluşturan başlıca çakıltaşı, kumtaşı ve çamurtaşı ardalanmasından oluşan bu birim, genellikle az belirgin kalın tabakalı, kırmızımsı kahve, grimsi renklerde çakıltaşlarından oluşmaktadır. Orta-kötü boylanmalı bir istif sunan bu çakıltaşı birimi, yarı köşeli ve kısmen yuvarlak çakıllardan oluşmaktadır. Oldukça büyük çapraz katmanlanmanın egemen olduğu Maymudağı Üyesine ait bu tortullar, karasal bir ortamda çökelmiştir. Maymundağı Üyesine ait çökellerin kalınlığı, yaklaşık olarak 1500 metredir (Toker, 2008). 
Genel olarak molas karakterinde bir istif sunan Çardak Formasyonu, altta bulunan Armutalanı Formasyonu ile uyumlu, üstte yer alan Hayrettin Formasyonu ile yanal ve düşey yönde geçişlidir. Formasyonun toplam kalınlığı 2000 metreyi geçmektedir (Şenel, 1997).

Çardak Formasyonu kadar geniş bir alanda yayılım gösteren ve egemen olarak çamurtaşı, çakıltaşı ve kumtaşlarından oluşan birim, bu çalışmada Hayrettin Formasyonu olarak tanımlanmıştır. Formasyon adı ilk kez Göktaş vd. (1989) tarafından adlandırılmıştır. Hayrettin Formasyonu, sadece Hayrettin Köyü civarında değil, aynı zamanda havzanın daha güney kesimlerinde, Sarıkavak ve Güney köylerinden başlayarak Yukarıyenice, Örtülü, Çiftlik, Yayla, Hisaralan ve İdrisköylerini ve Dazkırı ilçesini de içine alan bir bölgede yayılım gösterir. Hayrettin Formasyonu, egemen olarak ince-orta kalın tabakalı, açık gri, yeşilimsi gri, açık kahve, kirli sarı renkli, kalın konglomera ve ara seviyelerde kumtaşı ve çamurtaşı ardalanmasından oluşmaktadır. Hayrettin Formasyonunun egemen bileşeni olan kumtaşları genellikle sarımsı kahverengimsi görünümde, ince kumdan kaba kuma kadar değişen aralıkta tane boyuna sahip ve ince-orta-kalın tabakalıdır (Göktaş vd.1989).

$\mathrm{Bu}$ çökellerin üzerine, Pliyosen yaşlı Çameli formasyonu uyumsuz olarak gelmektedir (Göktaş ve diğ., 1989). Araştırma sahasında Kuvaterner yaşlı birimler ise Sarıkavak köyü civarındaki travertenler ile Maymun Dağı eteklerindeki birikinti koni-yelpaze ve vadi tabanlarındaki alüvyal dolgulardan oluşmaktadır.

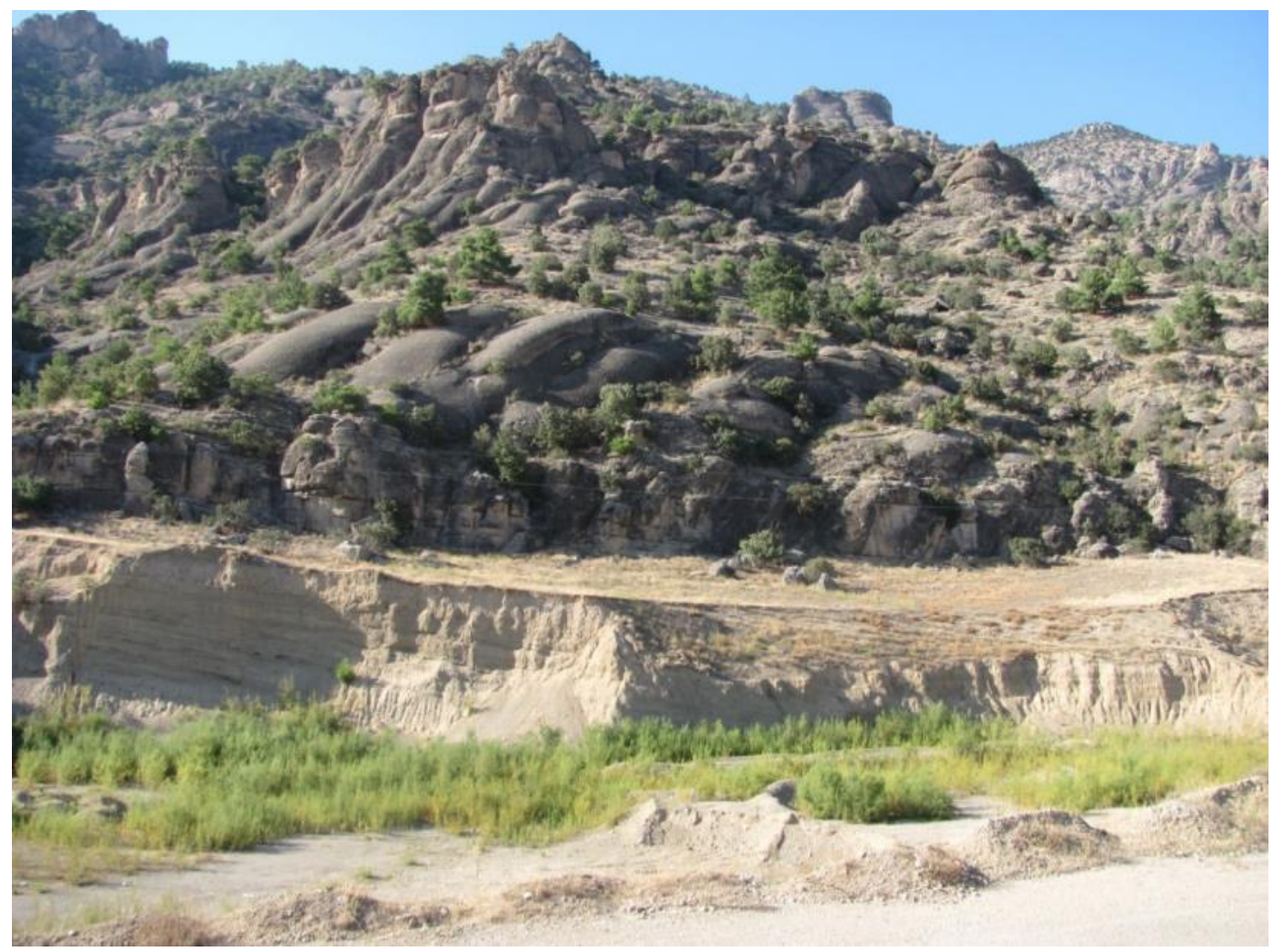

Foto 1. Çardak Formasyonu (Maymun Dağı Güneydoğusu)

Maymun Dağının özelikle kuzeyinde akarsu yataklarında bulunan alüvyonlar, güneyde yeralan birikinti koni-yelpazeleri ve yamaç döküntüleri Kuvaterner'i temsil eder. (Şekil 2). 


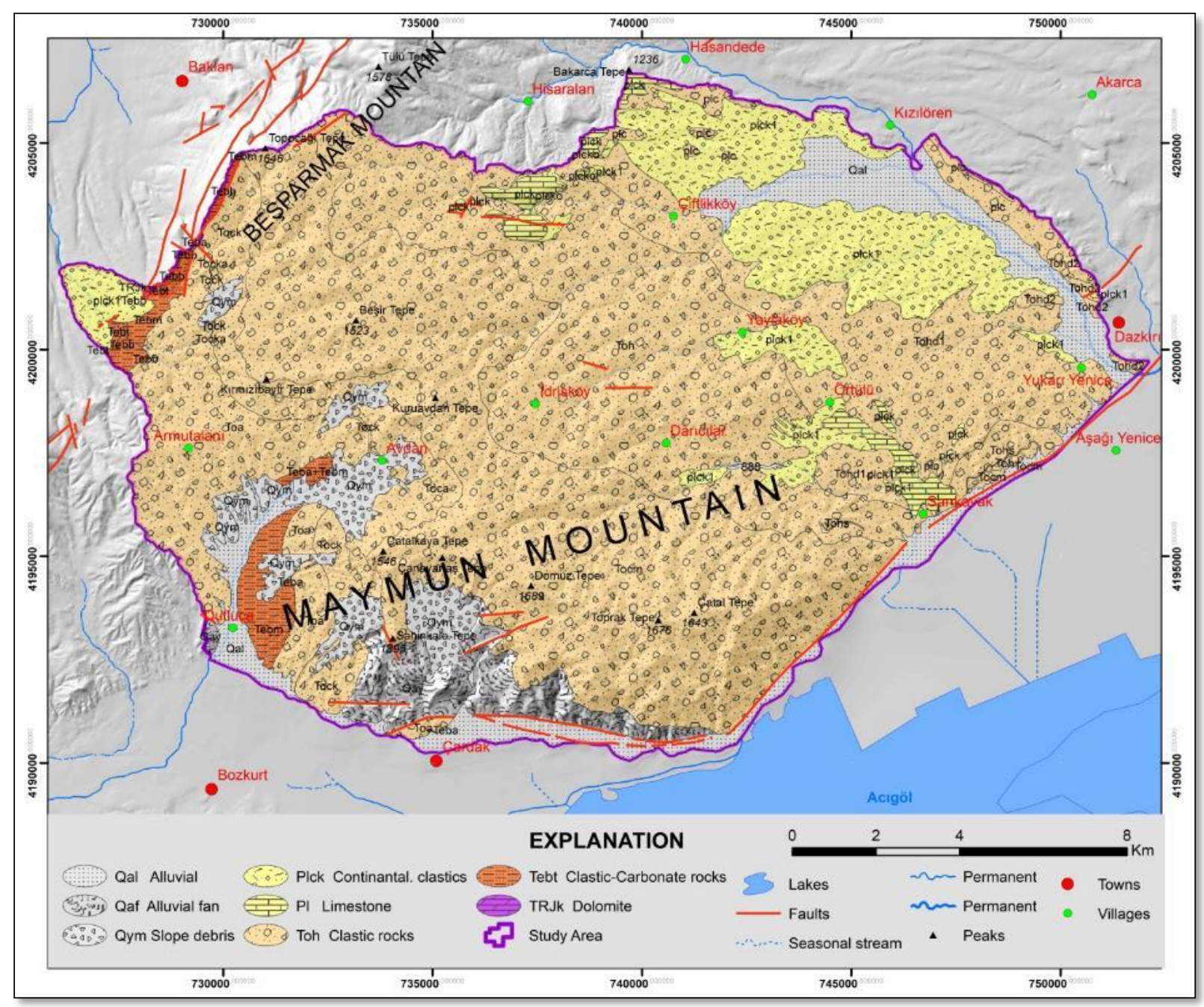

Şekil 2. Maymun Dağının Jeoloji Haritası

Araştırma alanı ve yakın çevresi, Miyosen sonunda oluşmaya başlayan, açılma türü bir tektonik rejimin denetimi altında gelişimini sürdüren, Ege Bölgesi horst-graben sistemi içinde yer alır ve bu sistemin doğusunda bulunur. Kuzeyde Çivril-Dinar güneyde acıgöl olmak üzere iki graben ortasındaki yükselim sahasına karşıllı gelmektedir. Saha, birbirini dik açıyla kesen fay zonları ile karakterize edilir (Koçyiğit, 1984; 2005; Koçyiğit vd., 2000; Gürbüz vd., 2012). Bu alanlarda tektonik yapı bir takım basamak faylardan oluşur. Sahadaki faylanma olayları sonucunda Çivril ovasının bulunduğu alan çökerken Beşparmak Dağları'nın bulunduğu kesim yükselmiş ve aynı zamanda güneydoğuya Acıgöl grabenine doğru çarpılmıştır. Daha sonra Acıgöl grabeninin kuzey kesiminde kırılmalar meydana gelerek Maymun Dağ 1 horstu kuzeydoğuya doğru çarpılarak yükselmiştir. Böylece Maymun Dağının oluşumu başlamıştır (Ege, vd., 2019).

Dinar grabeni etkin eğim atımlı faylar tarafından şekillendirilmiş olup, NW-SE yönünde uzun eksene sahiptir. Gerek Dinar gerekse Çivril grabenleri Akdağ, Beşparmak Dağları gibi horstlar tarafından sınırlandırılmaktadır. Sahanın şekillenmesinde tektonik olayların etkisi oldukça fazla olmuştur (Ege, vd., 2019). Yöre, 1 Ekim 1995 tarihli Dinar ve 8 Ağustos 2019 tarihli Çardak-Baklan depremlerinin de işaret ettiği üzere tektonik açıdan aktiftir.

Batı Anadolu'da orojenik çökmeye ve K-G genişleme tektoniğine bağlı olarak KD-GB, D$\mathrm{B}$ ve KB-GD doğrultulu birçok grabenler gelişmiştir. Genişleme rejiminin kontrolünde gelişen D-B, 
KD ve KB gidişli faylar (Koçyiğit, 1984, Koçyiğit ve diğ., 2000), günümüzde Batı Anadolu'da depremsellik açısından en aktif fay sistemini meydana getirmektedir. KD-GB uzanımlı grabenlerden biri olan Acıgöl Grabeni, çalışma alanının güneyinde, Tersiyer yaşlı tortulların önünde gelişmiş, aktif normal faylarla sınırlandırılan genç bir havzadır. Acıgöl grabeni, kuzeydoğusunda Çivril-Baklan grabeni, kuzeydoğusunda Dinar grabeni, güneybatısında Denizli grabeni ve güneyinde Burdur grabeni ile sınırlandırılmış bir çöküntü alanıdır. Çardak-Dazkırı havzasını çevreleyen bu grabenlerin sınır fayları da, düşey atımlı normal faylardır. Çalışma alanı ve yakın çevresinde gözlenen belirgin fay sistemleri; Baklan fayı, Maymundağı fayı ve Dinar fayıdır. Ayrıca Acıgöl grabenini güneyden sınırlayan Acıgöl fayı da tektonik açıdan oldukça aktif sol yanal bileşene sahip normal bir faydır. Acıgöl fayı, Maymundağı fayına göre oldukça belirgin bir morfoloji sunmaktadır (Toker, 2008).

Araştırma sahasının genel fiziki coğrafya özellikleri kuzeyden güneye doğru asimetrik bir yapısı olan Maymun Dağının en alçak yeri Acıgöl ve civarında 660 m'den başlamaktadır. En yüksek yeri ise Domuz Tepe'de 1689 m'ye ulaşmaktadır. Tamamen Oligosen yaşlı konglomeralardan oluşan Maymun Dağı üzerinde tabakalar hafif kuzeye doğru eğimli olup güney kesimde tabakaların baş kısımları çok keskin diklikler oluşturmaktadır. Dağın en zirve noktalarını Çatal Tepe $(1643 \mathrm{~m})$, Toprak Tepe $(1676 \mathrm{~m})$, Canavartaş Tepe $(1623 \mathrm{~m})$, Çatalkaya Tepe $(1546 \mathrm{~m})$ ve en kuzeyde Beşir Tepe $(1523 \mathrm{~m})$ en yüksek tepeleri meydana getirmektedir. Bunların dışında özellikle Dazkırı ilçe merkezi batısında Yaylaköy-İdris köy arasında güneyde fay façetaları üzerinde irili ufaklı birçok küçük tepeler yer almaktadır (Şekil, 2).

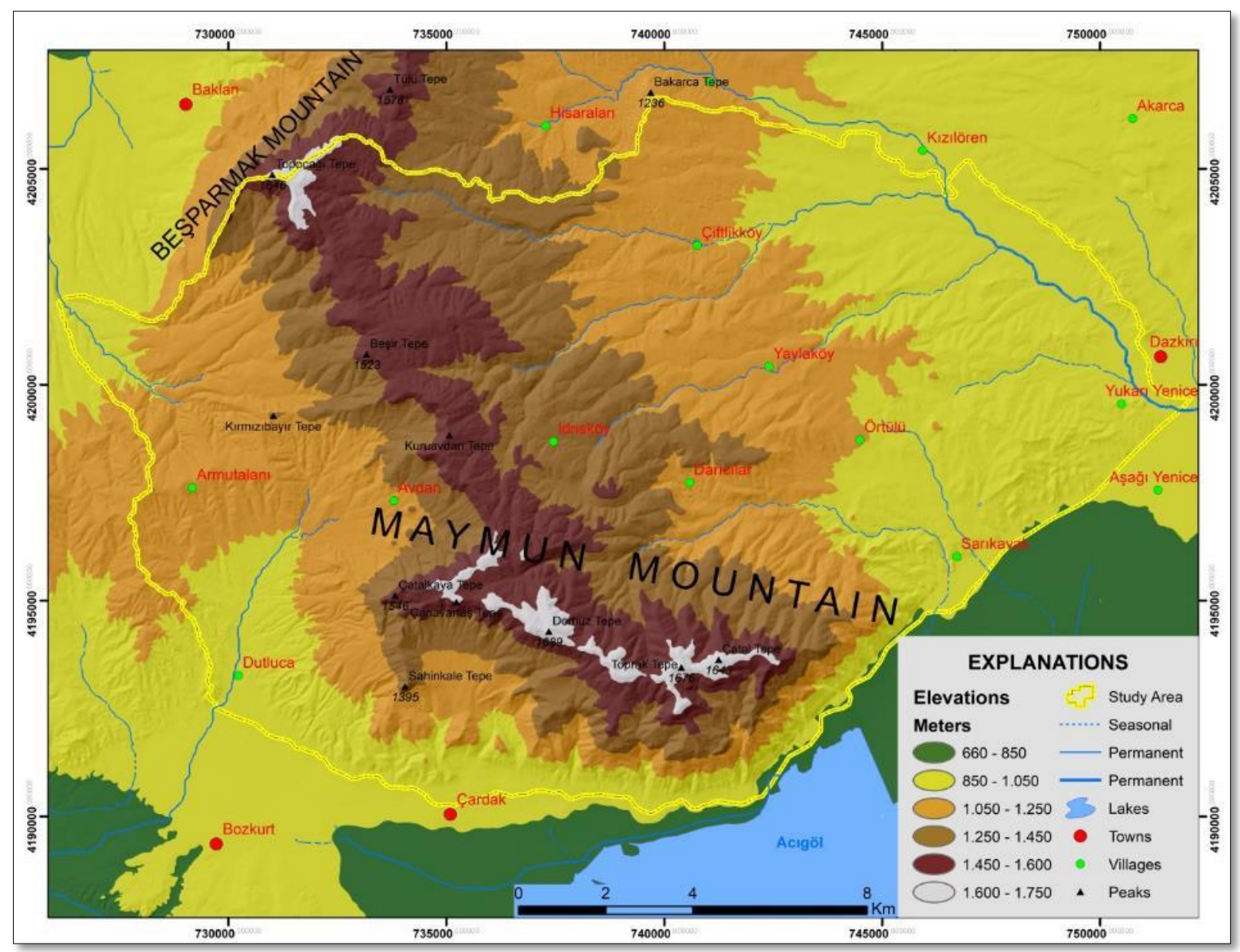

Şekil 3. Maymun Dağının Fiziki Haritası 


\section{Jeomorfometrik Analizler ve Bulgular}

Araştırmanın bu bölümünde Maymun Dağının drenaj özellikleri, hipsometrik eğri $\left(\mathrm{H}_{\mathrm{e}}\right)$ hipsometrik integral $\left(\mathrm{H}_{\mathrm{i}}\right)$, dağönü sinüslük indeksi $\left(\mathrm{S}_{\mathrm{mf}}\right)$, havza asimetrisi $(\mathrm{T})$, vadi tabanı genişliğgi vadi yüksekliği oranı $\left(\mathrm{V}_{\mathrm{f}}\right)$, üçgen yüzey (façeta) indeksi $\left(\mathrm{P}_{\mathrm{f}}\right)$, eğim ve bakı özellikleri hesaplanmış, çıkan sonuçlar yapılan diğer çalışmalarla ve arazi gözlemleri ile karşılaştırılarak havzanın morfometrik özellikleri ele alınmıştır.

\subsection{Drenaj Özellikleri}

İnceleme alanında genel olarak dandritik drenaj tipi görülmektedir. Akarsuların bazı bölümlerinde faylanmanın etkisi ile kancalı drenaj oluşmuştur. Fay hatları ile kancalı drenaj arasında sıkı bir ilişki olduğu çeşitli yazarlar tarafından da ifade edilmiştir (Efe, 1994; Zeybek, 2010; Öztürk, 2008; Ege, vd. 2019). Maymun Dağı'nda havzaları şekillendiren faylar akarsulara da yön vermiştir. $\mathrm{Bu}$ nedenle akarsular kuzey güney istikametinde akış gösterirken ani olarak doğuya veya batıya doğru yönlenirler. Akarsuların membaa kısımlarında fayların etkisi ile kanca şeklinde oldukları görülmekle beraber hakim olan drenaj tipi dandritik drenaj tipidir (Şekil 4).

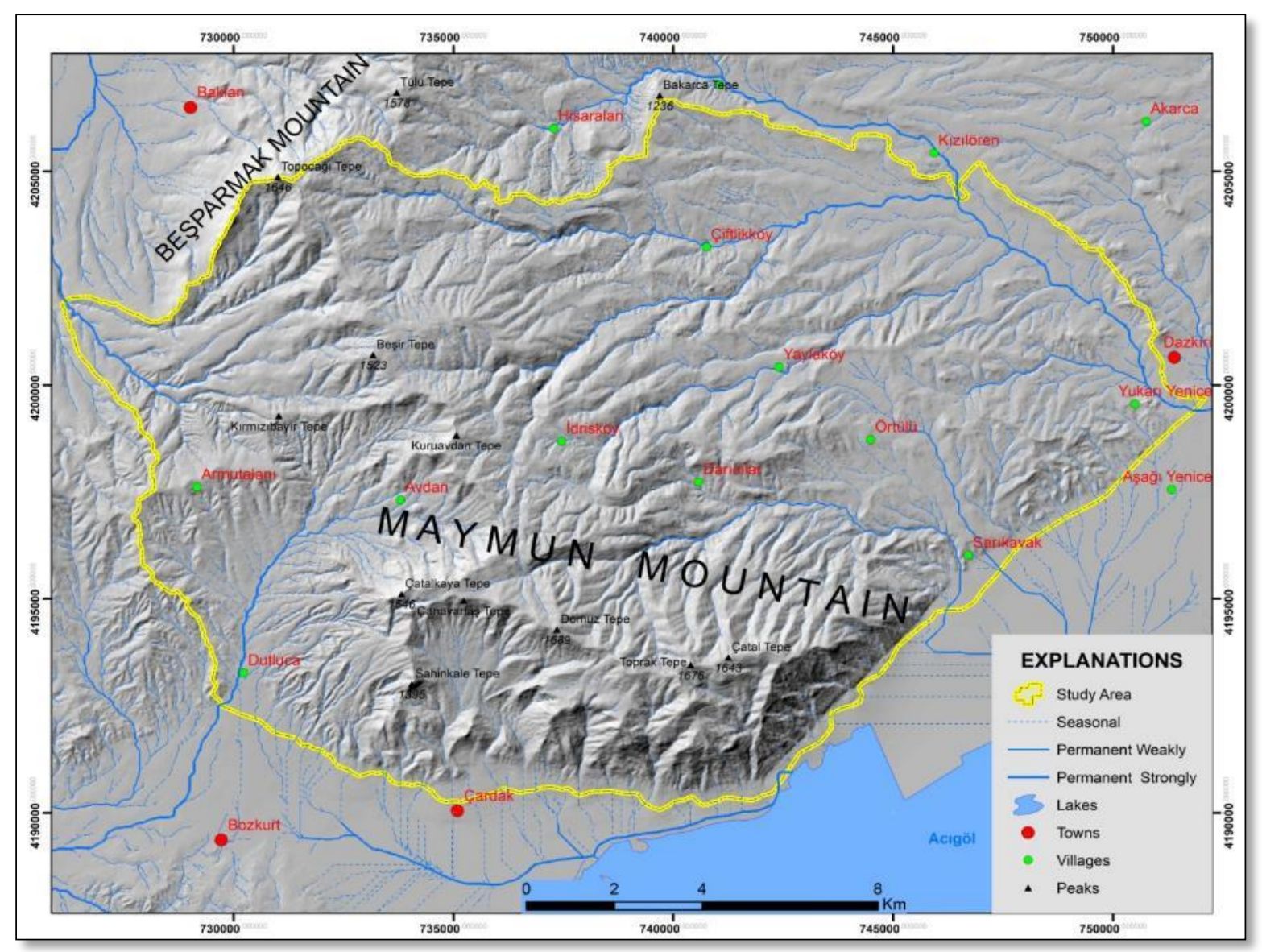

Şekil 4. Maymun Dağının Hidrografya Haritası

\subsection{Hipsometrik Eğri (He) ve Hipsometrik İntegral (Hi)}

Hipsometrik eğri bir alandaki yükseklik dağılımının tüm geride kalan yüzeye göre değerlendirilmesini esas alan bir kavramdır. İntegrali hesaplamada havzanın maksimum, minimum ve ortalama yükseklik değerleri kullanılır (Mayer, 1990; Özdemir, 2011). Hipsometrik integral, Hi = H - Hmin./Hmax. - Hmin formülü yani ortalama en yüksek-en düşük yükseltiler ve ortalama yükselti 
değeri ile hesaplanır. Böylece elde edilen sonuçlar birçok farklı drenaj havzasının karşılıklı değerlendirilmesinde önemli bir rol oynamaktadır. Maymun Dağ 1 Üzerinde 10 havza ayırt edilmiş ve bunların hipsometrik eğri (He) ve integral (Hi) değerleri hesaplanmıştır (Şekil, 5; Tablo1).

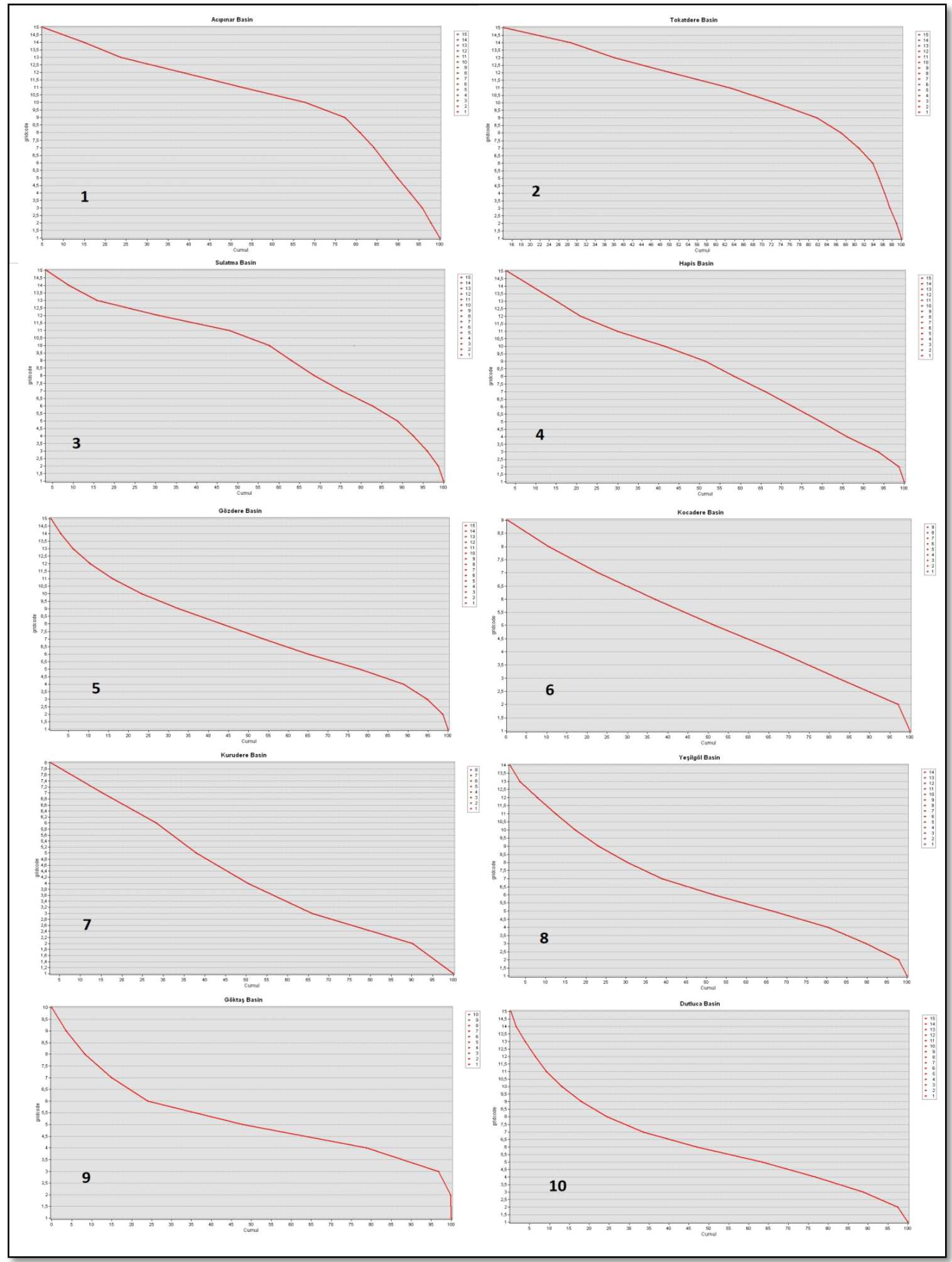

Şekil 5. Maymun Dağı Üzerinde Seçilmiş Havzalardan Hipsometrik Eğriler (He). 
Tablo 1: Maymun Dağı Üzerinde Bulunan Havzalarda Hipsometrik İntegral (Hi) Değerleri

\begin{tabular}{|c|c|c|c|c|c|}
\hline $\begin{array}{c}\text { Havza } \\
\text { No }\end{array}$ & Havza Adı & $\begin{array}{c}\text { Ortalama } \\
\text { Yükseklik }\end{array}$ & $\begin{array}{c}\text { Maximum } \\
\text { Yükseklik }\end{array}$ & $\begin{array}{c}\text { Minumum } \\
\text { Yükseklik }\end{array}$ & $\begin{array}{c}\text { Hipsometrik } \\
\text { İntegral }\end{array}$ \\
\hline 1 & Acıpınardere & 1380 & 1647 & 895 & 0,64 \\
\hline 2 & Tokatdere & 1430 & 1076 & 895 & 0,69 \\
\hline 3 & Sulatmadere & 1350 & 1651 & 910 & 0,59 \\
\hline 4 & Hapisdere & 1318 & 1687 & 934 & 0,51 \\
\hline 5 & Gözdere & 1242 & 1652 & 912 & 0,45 \\
\hline 6 & Kocadere & 1289 & 1688 & 871 & 0,51 \\
\hline 7 & Kurudere & 1191 & 1646 & 875 & 0,41 \\
\hline 8 & Yeşilgöldere & 1236 & 1647 & 956 & 0,40 \\
\hline 9 & Göktaşdere & 1062 & 1312 & 867 & 0,43 \\
\hline 10 & Dutlucadere & 1177 & 1644 & 909 & 0,36 \\
\hline Ortalama & & & & & 0,49 \\
\hline
\end{tabular}

Yapılan hesaplama sonucunda elde edilen grafikte iç bükey şeklin çıkması havzadaki topografyanın yaşl11ık evresinde olduğunu ve akarsuların akım gücünün düştüğünü, taşınan materyalin azaldığını daha çok biriktirmenin hakim olduğunu gösterir. Elde edilen grafikte dış bükey şeklin çıkması, havzadaki topografyanın daha genç olduğu, akarsuların akım gücünün daha yüksek olduğu, akarsudan taşınan yük miktarının fazla olduğu, akarsu yatağında birikmeden daha çok aşınmanın hakim olduğu söylenebilir.

Maymun Dağı üzerinde yer alan Acıpınar, Tokatdere ve Sulatma Havzaları tamamen dış bükey bir eğriye sahiptir. İntegral değerleri \% 60 civarında olan Acıpınar $(0,64)$, Tokatdere $(0,69)$ ve Sulatma Havzası da $(0,59)$ hipsometrik eğrilerinde dış bükey çıkması bu havzaların oldukça genç, tektonik açıdan aktif olduklarını göstermektedir. Bununla beraber Hapisdere, Gözdere ve Kocadere Havzaları hipsometrik eğrisi nispeten olgun havzayı göstermektedir. Hapisdere $(0,51)$, Gözdere $(0,45)$ ve Kocadere $(0,51)$ havzalarının hipsometrik integral değerleri de olgun havzayı işaret etmektedir. Maymun Dağı üzerinde hipsometrik eğrisi olgun havzayı ifade eden ve hipsometrik integral değerleri \% 40 civarında olan Kurudere $(0,41)$, Dutluca $(0,36)$ ve Yeşilgöldere $(0,40)$ havzaları mevcuttur. Hipsometrik eğri ve integral değerleri 3 gruba ayrılan havzalar Maymun Dağının dört bir yanında tektonik aktivitenin farklılık arz ettiğini göstermektedir.

\subsection{Dağönü Sinüslük İndeksi (Smf)}

$\mathrm{Bu}$ indis dağ yarmaya çalışan erozyonal kuvvetler ile dağın ön tarafını düz bir hat şeklinde tutmaya çalışan tektonizma arasındaki dengeyi ifade eder. Böylece tektonizmanın yoğun olduğu bölgelerde arazi henüz çok fazla parçalanmadığı için Smf değerleri daha düşük çıkar.

Formül olarak Smf = Lmf / Ls kullanılır. Bull (1977) tarafindan önerilen formülde: dağ önünün düz çizgi uzunluğu Ls, dağın eteği boyunca dağ önü uzunluğu ise Lmf' dir. (Keller ve Pinter, 2002). Özellikle fay aynalarında bu değerin 1'e çok yakın olduğu gözlenir. Zaman ilerledikçe flüvyal süreçlerin daha etkin olması tektonizmanın etkisinin yavaş yavaş silindiği alanlarda Smf değerleri yükselir. Maymun Dağı üzerinde 5 ayrı noktada Smf değeri hesaplanmıştır. Buna göre dağın güneyinde, (Çardak civarında) ve güneydoğusunda $1.2 \mathrm{Smf}$ değerleri ile en şiddetli ve de en yeni tektonik aktivitenin olduğunu göstermektedir. Bu alan aynı zamanda Acıgöl grabeninin kuzey sınırına karşılık gelmektedir. Bununla beraber dağın tam tersi istikametini oluşturan kuzey batı kesiminde Baklan grabeninin güney sınırını oluşturan noktada Smf değerinin 2.92'lik bir değer gösterdiği hesaplanmıştır. Bu alanda tektonik aktiviteden daha ziyade flüvyal süreçlerin şekillendirmede daha belirgin duruma geçtiğini söylemek mümkündür. Maymun Dağının kuzey doğusunu oluşturan ve de tabaka dalımlarının kuzey batıya doğru olduğu sahada Smf değerinin 3.35 ile en yüksek oranda olduğu hesaplanmıştır. Bu durum dağın bu kesiminde tektonik aktivitenin 
rolünün çok fazla olmadığı, şekillendirmede flüvyal süreçlerin hakim olduğunu göstermektedir. $\mathrm{Bu}$ alan Kurudere ve Kocadere havzasına karşılık gelmektedir (Şekil, 6).

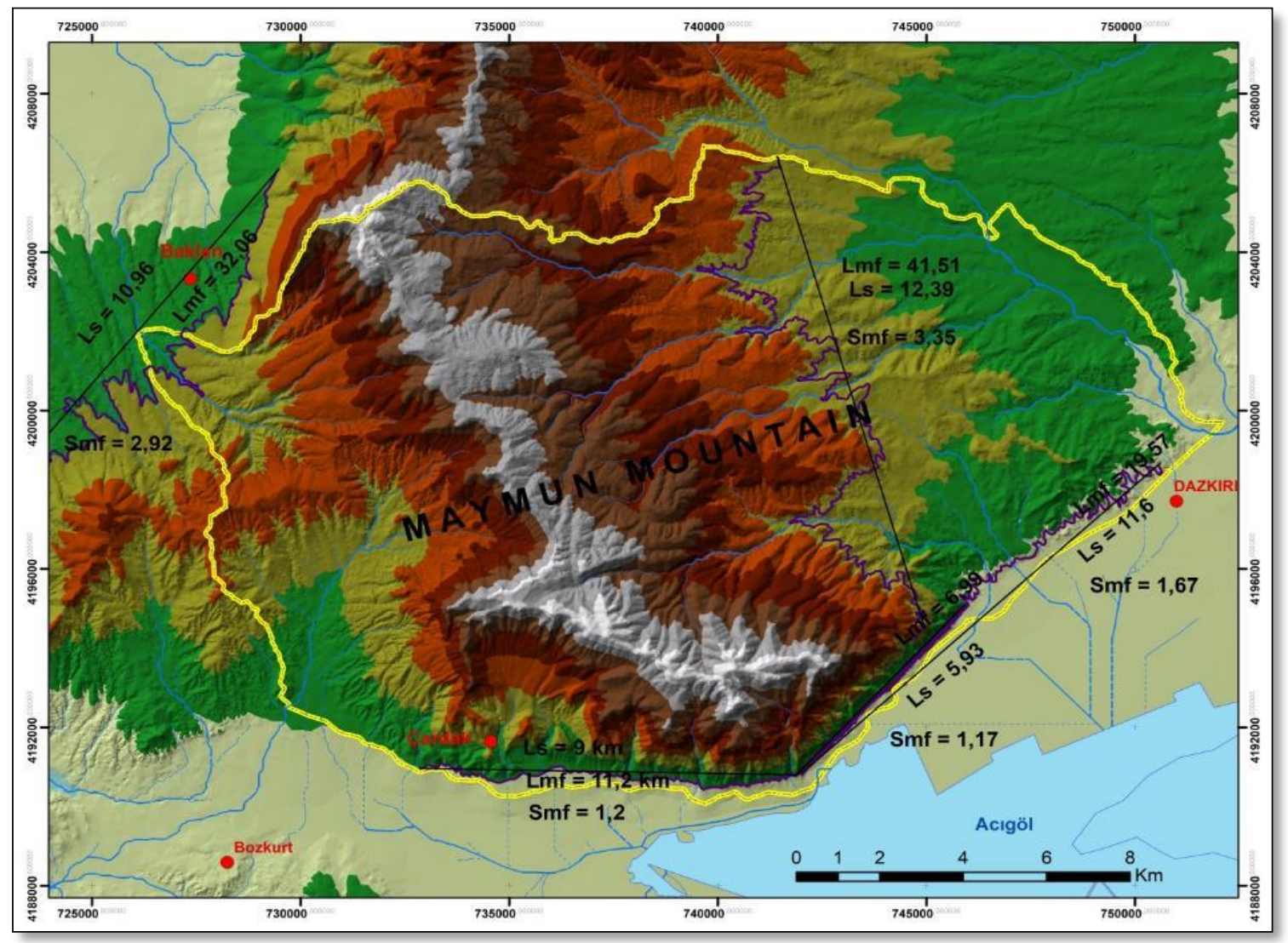

Şekil 6. Maymun Dağı Üzerinde Dağönü Sinüslük İndeks ( $\left.\mathrm{S}_{\mathrm{mf}}\right)$ Değerleri 


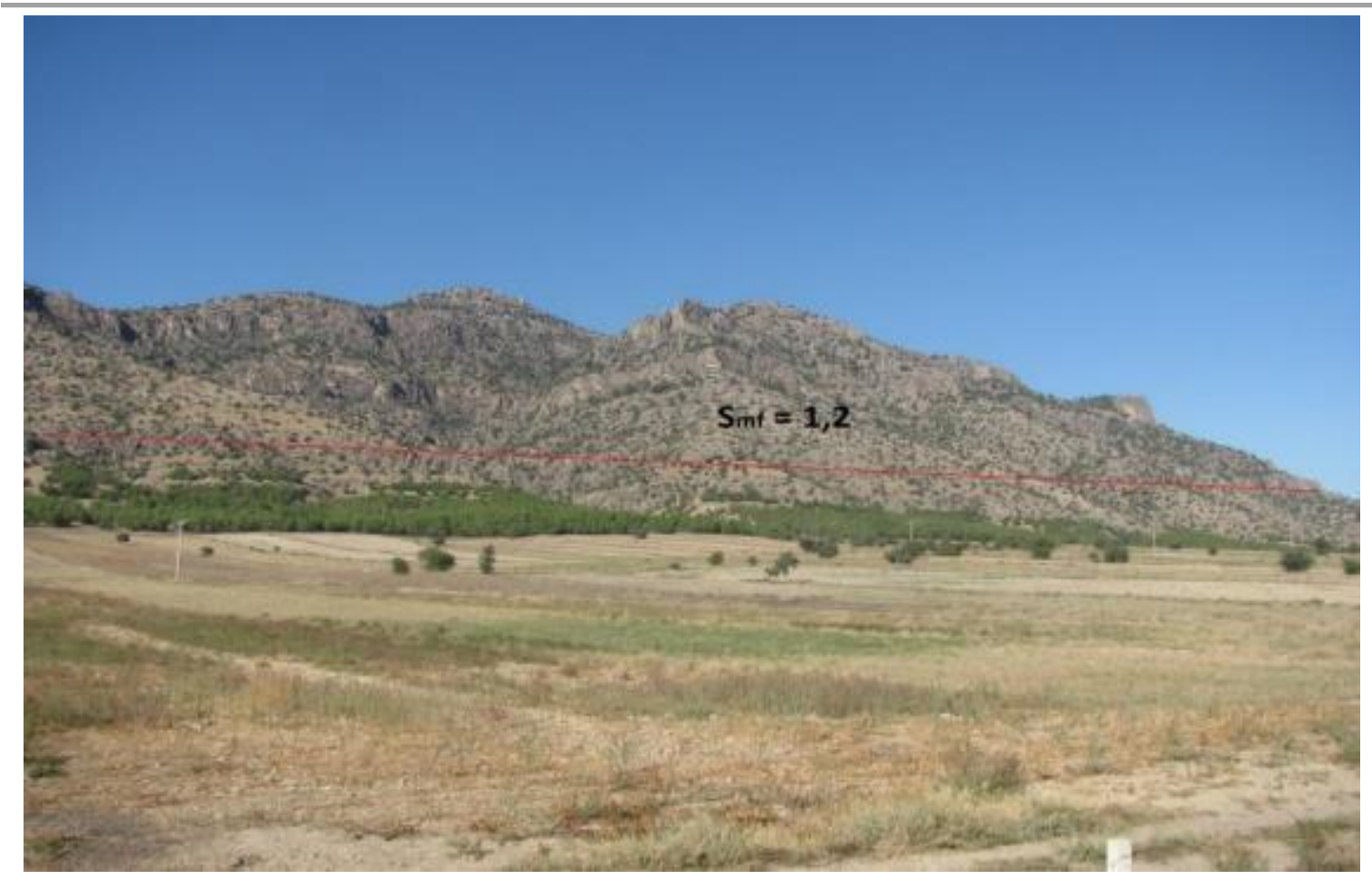

Foto 2. Maymun Dağının Güney Kesimi’nde Dağönü Sinüslük İndeksi (Smf)

\subsection{Vadi Tabanı Genişliği-Vadi Tabanı Oranı (Vf)}

Vadi Tabanı Genişliği-Vadi Tabanı Oranı (Vf) indisi tektonizmanın vadi yamaç profilleri üzerindeki etkilerini belirlemek için kullanılmaktadır.

Formül; $[\mathrm{Vf}=2 . \mathrm{Vfw} /($ Eld-Esc $)+($ Erd-Esc $)]$ şeklindedir.

Burada Vf değerlerinin birden küçük olan vadiler genellikle yeni kurulmakta olan kertik vadilerdir. $\mathrm{Bu}$ alanlar tektonizmanın çok aktif olduğu genç sahalarda akarsuyun derine aşındırmasının meydana getirdiği $\mathrm{V}$ şekilli vadiler olarak sınıflandırılır. Bir ve bir buçuk arasındaki Vf değerleri orta derece aktif tektoniği, bir buçuktan büyük olan değerler ise aşındırmadan çok artık biriktirmenin hakim olduğu U profilli tabanlı vadiler olarak ayırt edilir. Maymun Dağ 1 üzerinde hemen hemen her havzada 2-3 noktadan akarsu vadisine dikine kesitler alınarak toplamda 23 noktada Vf değeri hesaplanmıştır. Genel olarak akarsuların memba kısımlarında birden düşük Vf değerleri bulunurken akarsuların mansap kısımlarında 1.5'un üzerinde Vf değerleri hesaplanmıştır. Elde edilen sonuçlara göre aktif tektonizmanın çok belirgin olduğu Hapisdere, Sulatma, Acıpınar ve Tokatdere havzalarında akarsuların tüm noktalarında 0,50 'den düşük Vf değerleri ile aktif tektonizmanın etkisi çok net olarak görülmektedir (Şekil, 7).

Maymun Dağı üzerinde en yüksek Vf değerleri Kurudere, Dutluca, Göktaş ve Yeşilgöldere havzalarında hesaplanmıştır. Bu alandaki Vf değerleri 1, 1,5 ve 2'nin üzerindedir. Bu durumda Maymun Dağı üzerinde tektonizmadan en az etkilenmiş olan bölümlerin kuzeydoğu ve güneybatı kesimlerin olduğu söylenebilir. Maymun Dağ 1 üzerinde genel yargı olarak bu havzalarında memba kısımları daha genç, mansab kısımları ise daha olgun bir durum göstermektedir. Böylece yukarı çı̆̆ırda $\mathrm{V}$ vadiler ve aşındırma, aşağı çı̆̆ırda ise tabanlı vadiler hakim olup biriktirme faaliyetleri daha etkin durumdadır (Şekil, 7; Tablo, 2). 
Tablo 2: Maymun Dağı Üzerinde Yer Alan Havzalarda Vadi Tabanı Genişliği-Vadi Tabanı Oranı (Vf) Değerleri Tablosu

\begin{tabular}{|c|l|r|r|r|}
\hline No & Havza Ad1 & Yukarı çı̆̆ır & Orta çı̆̆ır & Aşağı çı̆̆ır \\
\hline 1 & Kurudere havzası & 0,13 & 0,94 & 3,86 \\
\hline 2 & Göktaş havzası & 1,82 & & 3,64 \\
\hline 3 & Kocadere havzası & 0,29 & 0,27 & 2,03 \\
\hline 4 & Tokatdere havzas1 & 0,14 & 0,27 & \\
\hline 5 & Acıpınar havzası & 0,47 & 0,48 & \\
\hline 6 & Sulatma havzası & & 0,13 & \\
\hline 7 & Hapisdere havzas1 & 0,13 & 0,22 & \\
\hline 8 & Gözdere havzası & 1,57 & 0,40 & \\
\hline 9 & Dutluca havzas1 & 2,73 & 0,40 & 3,09 \\
\hline 10 & Yeşilgöldere havzas1 & 1,25 & 1,00 & 3,03 \\
\hline & ORTALAMA & 0,95 & 0,45 & 3,13 \\
\hline
\end{tabular}

Ortalama Vf değerlerine bakıldığında Maymun Dağının yüksek kesimlerinde havzaların yukarı çığırlarında 0,95 iken, orta çı̆̆ırlarında 0,45 gibi çok daha düşük değerin hesaplandığ görülmektedir. Bu durum Maymun Dağı üzerinde tektonik gençleşmelerin olduğunu ve de sahanın gençlik evresinde olduğunu göstermektedir. 


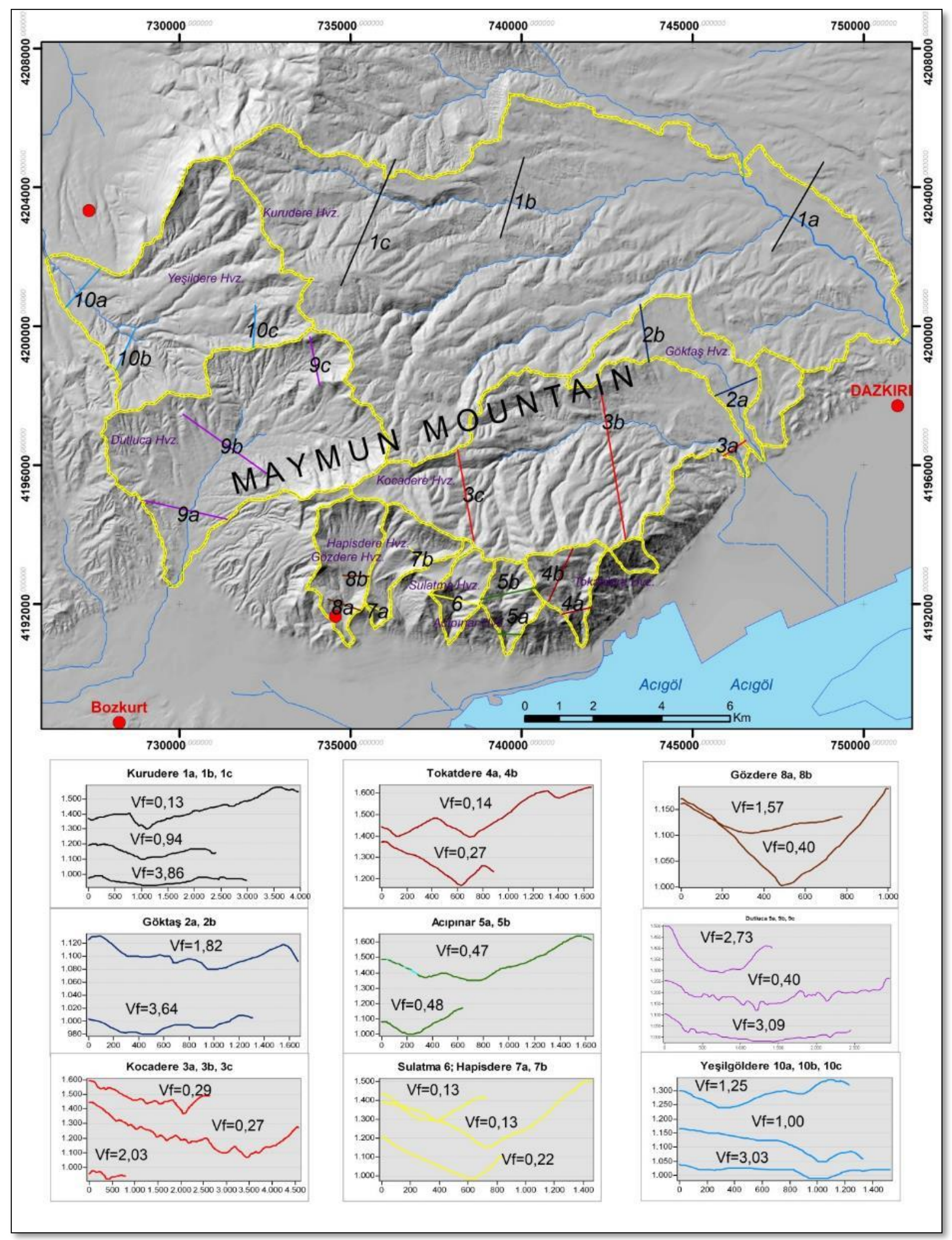

Şekil 7. Maymun Dağı Üzerindeki Havzalarda Vadi Tabanı Genişliği-Vadi Tabanı Oranı (Vf) Değerleri 


\subsection{Havza Asimetrisi}

Havza Asimetrisi indisi jeomorfoloji çalışmalarında tektonik aktivitelerin havza üzerindeki etkisini göstermesi bakımından önemli bir indistir (Öztürk ve Erginal, 2008). Bu indis bir havzanın hangi kısmının daha asimetrik olduğunu belirlemede kullanılır. Böylece aynı zaman da havzalardaki yan basınçların hangi istikametlerden olduğu da belirlenebilir. İlk olarak Cox (1994) tarafindan uygulanmıştır.

Formül; $\mathrm{T}=\mathrm{Da} / \mathrm{Dd}$ şeklindedir. Burada; $\mathrm{T}=$ Havza asimetrisi, $\mathrm{Da}=$ Orta eksen ile ana akarsu kolu arasındaki mesafe ve $\mathrm{Dd}=$ orta eksen ile drenaj havza sınırları arasındaki mesafedir.

Yapılan hesaplama sonucunda ortaya çıkan değer 0'a yaklaştıkça havza simetrik, 1'e yaklaştıkça havza asimetrik bir özellik göstermektedir. Maymun Dağı üzerinde mevcut havzaların çeşitli kısımlarından 31 noktada yapılan hesaplamalar sonucunda havza asimetrileri ortaya konulmaya çalışılmıştır. Buna göre gerek dağın asimetrik yapısından, gerekse tektonizmanın etkin olduğu kısımlarda havza asimetrisinin çok yüksek olduğu görülmektedir. Aşınma ve taşınma faaliyetlerinin normal seyrettiği noktalarda havza simetrisinin 0 'a yakın değerler gösterdiği söylenebilir. En yüksek havza asimetrisi Dutluca yerleşmesinin kuzeydoğusunda $(0,97)$ aktif faylara bağlı olarak birikinti yelpazesinin üzerinde görülür iken ana litoloji üzerinde görülen en yüksek asimetri Kurudere üzerinde $(0,76 ; 0,58)$ hesaplanmıştır. Bunların dışında da tektonizmanın en çok etkilediği Hapisdere $(0,62 ; 0,60 ; 0,43)$, Acıpınar $(0,44)$, Tokatdere $(0,46 ; 0,52)$ ve Kösüklerdere $(0,67 ; 0,56)$ havzalarında 1'e yakın değerlerin olduğu görülmektedir (Şekil, 8).

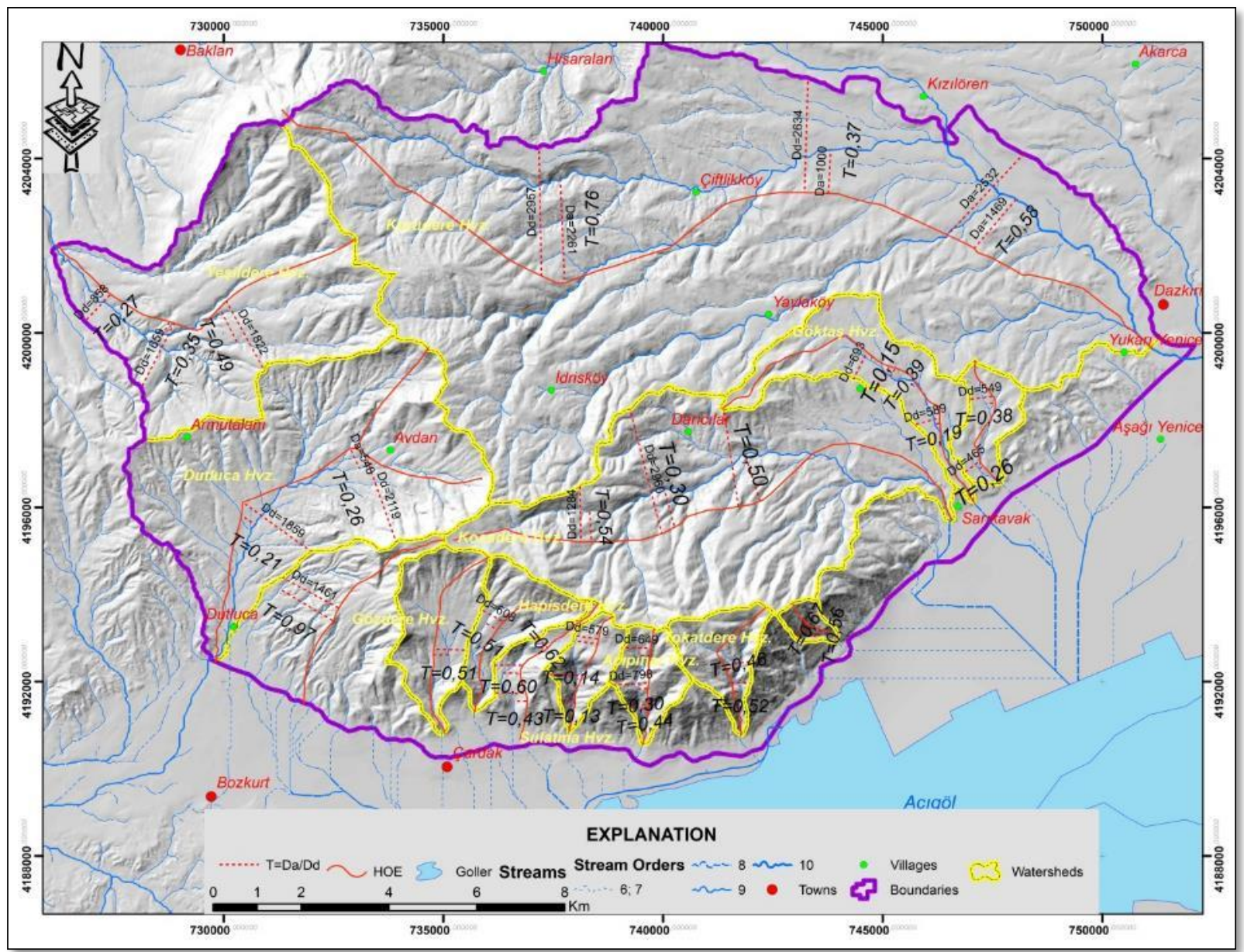

Şekil 8. Maymun Dağı Üzerinde Yer Alan Havzaların Asimetrik Değerleri 


\section{6. Üçgen yüzey (façeta) indeksi $\left(P_{\mathrm{f}}\right)$}

Dağ önlerinin topografyası, faylanma, erozyon ve tortulların depolanma oranları gibi evrimini belirleyen faktörlerden etkilenmektedir. Aktif faylar boyunca yükselmiş alanlardan akan nehirler dağ önlerini yarar ve bölerler. Örneğin, faylarla sınırlanmış bir blok, her iki tarafinda da düzenli olarak şekillenmiş, benzer büyüklükte ve şekilli vadiler oluşturacaktır. Bunlar aktif dağ önlerinde devam eden, geniş tabanları ve dar boğazları ile "şarap kadehi" olarak adlandırılan vadiler ile karakterize edilir. Ayrıca, bu yükselmeler doğrusal bir sıra ile geniş üçgen yüzeyler ve küçük dağ eteği yelpazeleri de yaratacaktır. Bu nedenle, dağ önleri boyunca üçgen yüzeylerin mesafeleri taban bloğu içindeki drenaj havzalarının oluşumunu etkiler (Mayer 1986; Burbank ve Anderson 2001; Topal, 1012'den aktarım ile). Maymun Dağının güney ve güneydoğu yamaçlarında çok tipik façetalara rastlanır. Façetalar gerisindeki yükselmeler faylanmanın birkaç kademede olduğunu da göstermektedir. Gerek $\mathrm{S}_{\mathrm{mf}}$ gerekse vadi tabanı genişliği-vadi tabanı oranı $\left(\mathrm{V}_{\mathrm{f}}\right)$ analizlerinde de tektonik açıdan en aktif sahaya karşılık gelen bu alan da, façetalar arasında gelişmiş olan vadilerden taşınan malzemelerin oluşturduğu birikinti konilerinin çok küçük olması, buna karşın üçgen yüzeylerin çok büyük olması aktif tektoniği göstermektedir (Şekil 9; Foto 3). Genellikle daha yaşlı dağlar ile ilişkilendirilen düşük aktifliğe sahip fay düzlemleri ise düşük indeks değerleri gösteren daha uzun üçgen yüzeyleri, dairesel tabanları ve düzensiz geniş mesafeli akarsuları ile ayrılırlar. Bu sebeple, üçgen yüzey indeksi (Pf) tektonik aktivitenin iyi bir belirleyicisidir (Burbank ve Anderson 2001).

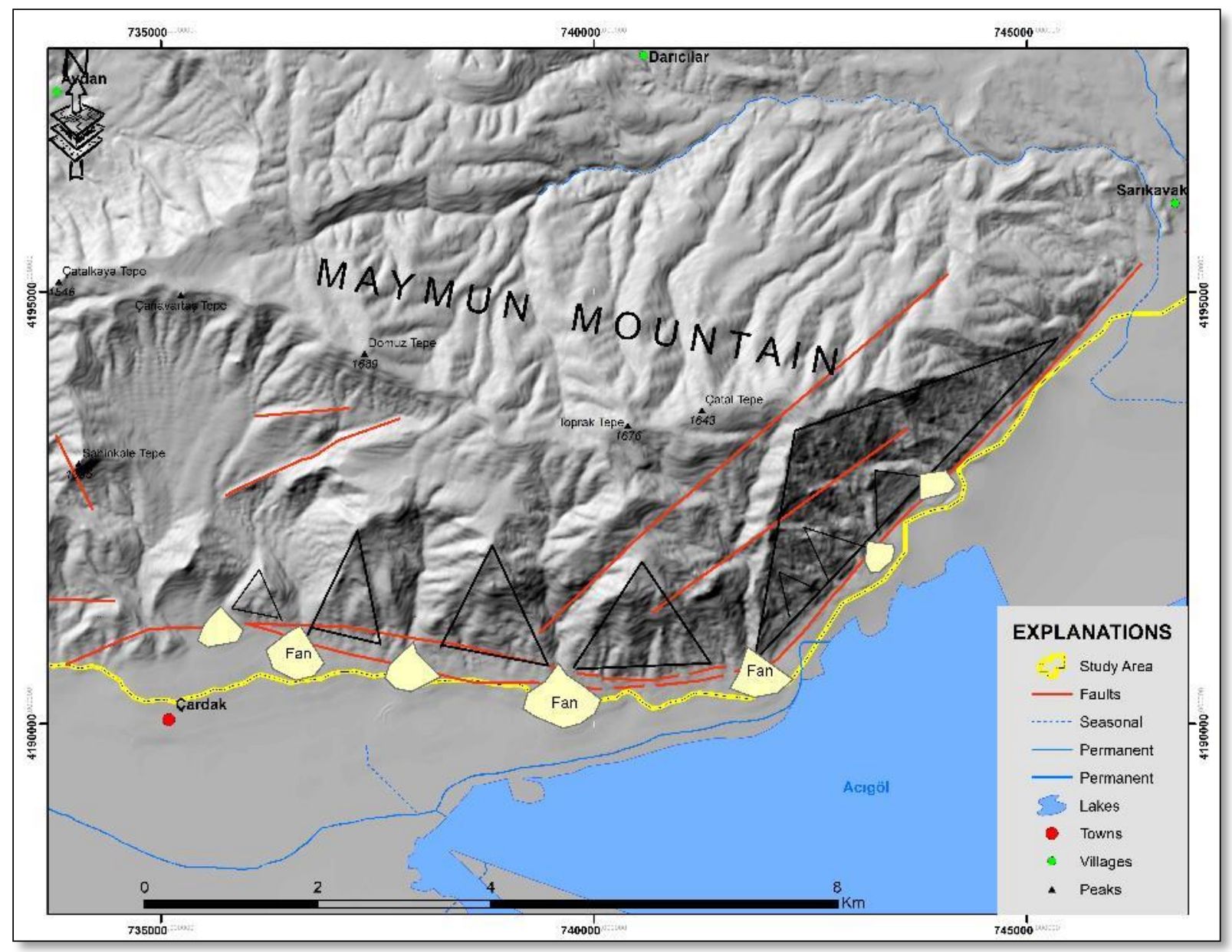

Şekil 9. Maymun Dağının Güney ve Güneydoğusunda Aktif Faylar, Üçgen Yüzeyler (Façetalar) ve Birikinti Konileri 


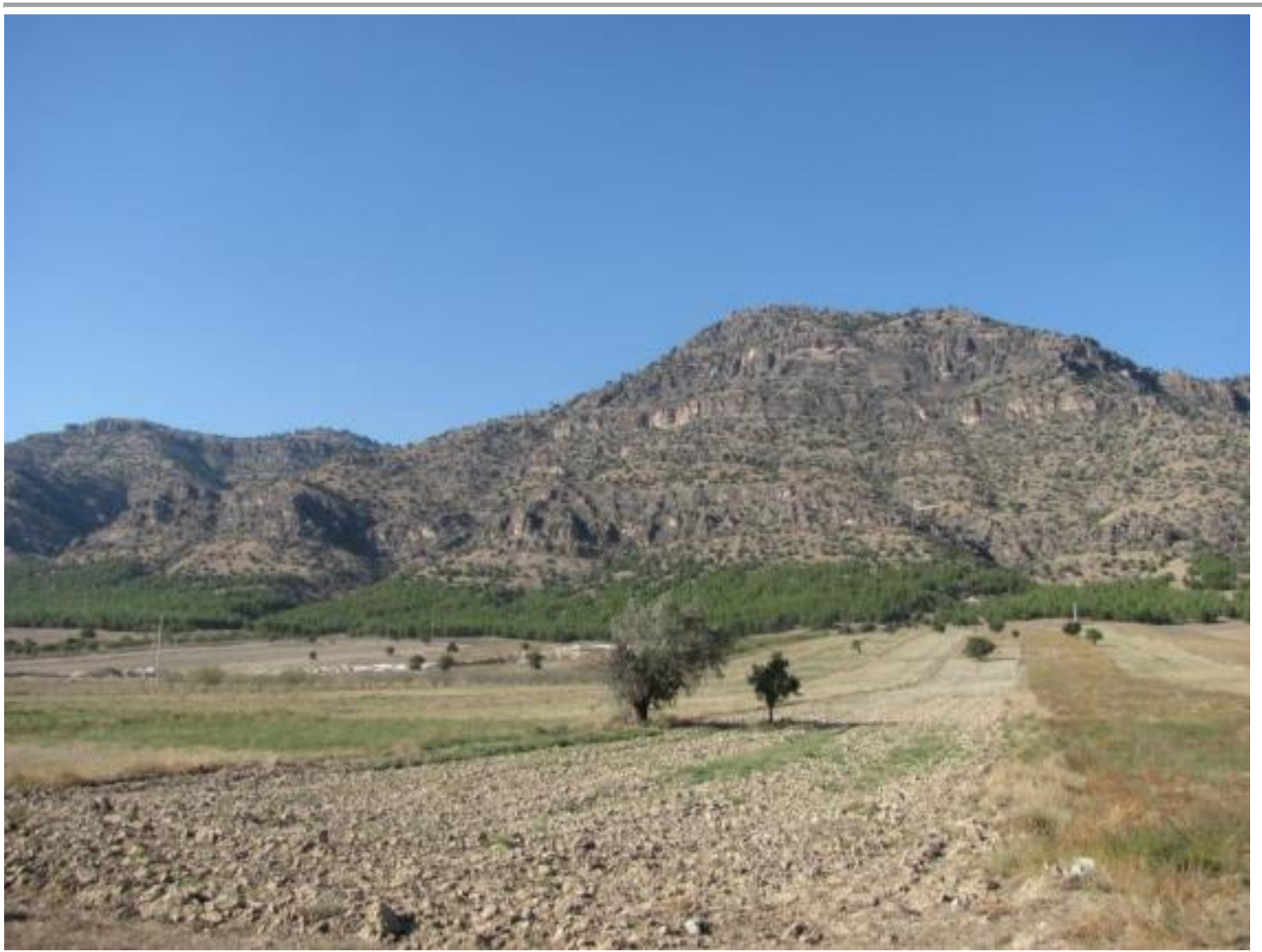

Foto 3. Maymun Dağı Güneyinde Façetalar

\subsection{Eğim ve Bakı Özellikleri}

Bir sahadaki eğim ve bakı özellikleri sahadaki jeomorfolojik özellikler, aktif faylanma ve tektonizmanın yapısı hakkında bilgi verir. Bu nedenle yapılan eğim ve bakı haritaları sahayı anlama ve yorumlamayı kolaylaştıracaktır (Simou vd., 2013). Eğim derecesinin düşük olduğu yerlerin yüzdesi fazla olan yerler daha çok yaşl1, eğim derecesinin yüksek olduğu yerlerin yüzdesi yüksek ise daha genç arazileri ifade etmektedir. Maymun Dağı üzerinde eğimi 0-1 arasında olan yerlerin yüzdesi sadece 1,1 ve eğimi 1-3 arasındaki yerlere karşılık gelen dalgalı düzlükler ise \% 17,27'dir. Bunun haricindeki alanlar az eğimli $(9,79)$, eğimli $(28,97)$, çok eğimli $(38,44)$ ve sarp araziler $(4,42)$ olarak $\%$ 82'lik bir orana sahiptir (Şekil 10 ve 11). Bu da Maymun Dağının yeni şekillenmekte olan genç bir dağlık kütle olduğunu göstermektedir. 


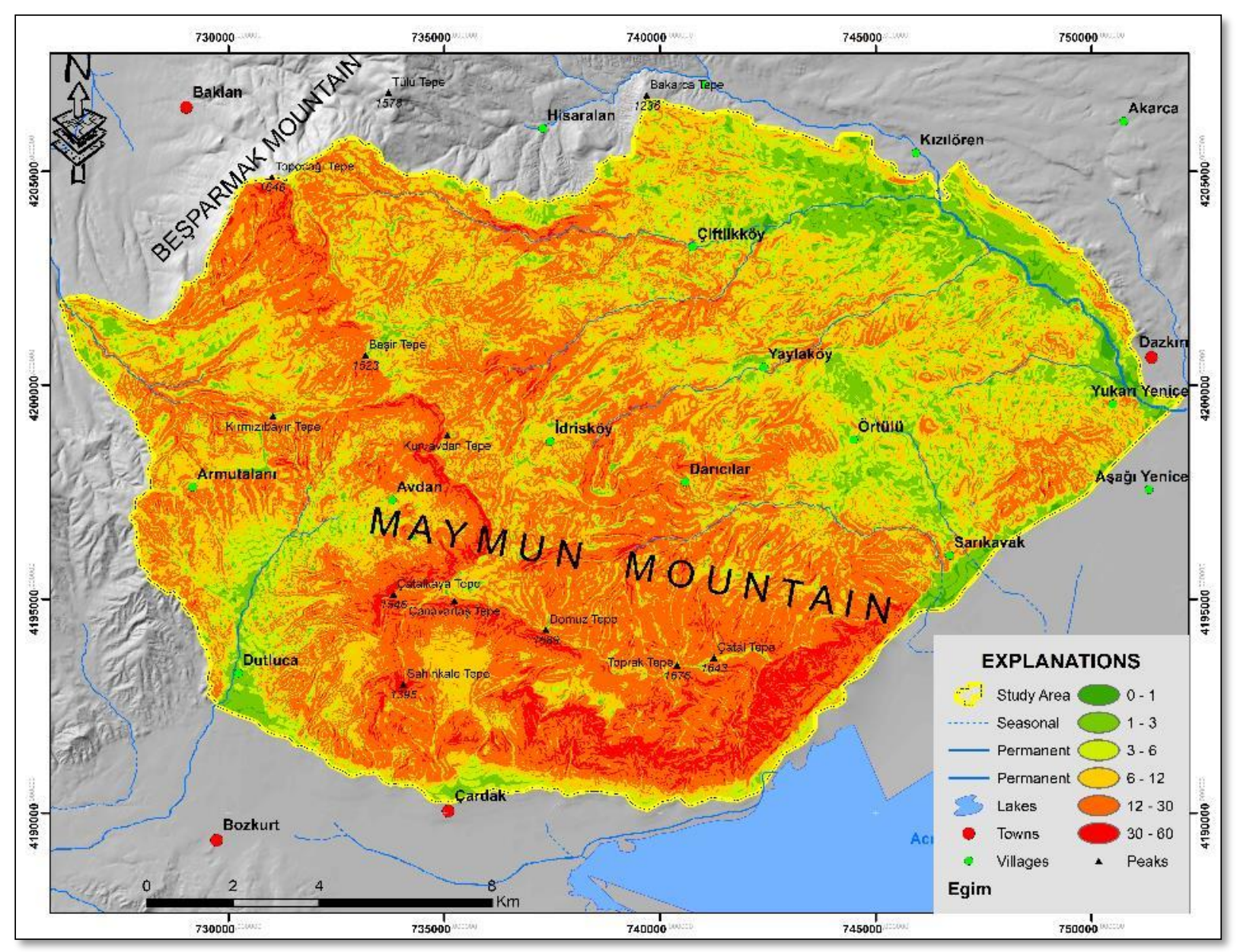

Şekil 10. Maymun Dağının Eğim Haritası

Tablo 3: Maymun Dağı Üzerinde Eğim Oranlarının Dağılışı

\begin{tabular}{|c|c|c|c|}
\hline Eğim Sınıfları (Derece olarak) & Shape_Area & Per \% & Genel \% \\
\hline Düz (0-1) & 3106813,51 & 1,10 & \multirow{2}{*}{$\begin{array}{c}\text { Düzlükler } \\
18,37\end{array}$} \\
\hline Dalgalı Düz (1-3) & 48758186,01 & 17,27 & \\
\hline Az Eğimli Yamaç (3-6) & 27624805,31 & 9,79 & \multirow{4}{*}{$\begin{array}{c}\text { Yamaçlar } \\
81,63 \\
\end{array}$} \\
\hline Eğimli Yamaç (6-12) & 81786365,19 & 28,97 & \\
\hline Çok Eğimli Yamaç (12-30) & 108521053,79 & 38,44 & \\
\hline Sarp Arazi (30-60) & 12477476,99 & 4,42 & \\
\hline Toplam & 282274700,81 & 100,00 & \\
\hline
\end{tabular}




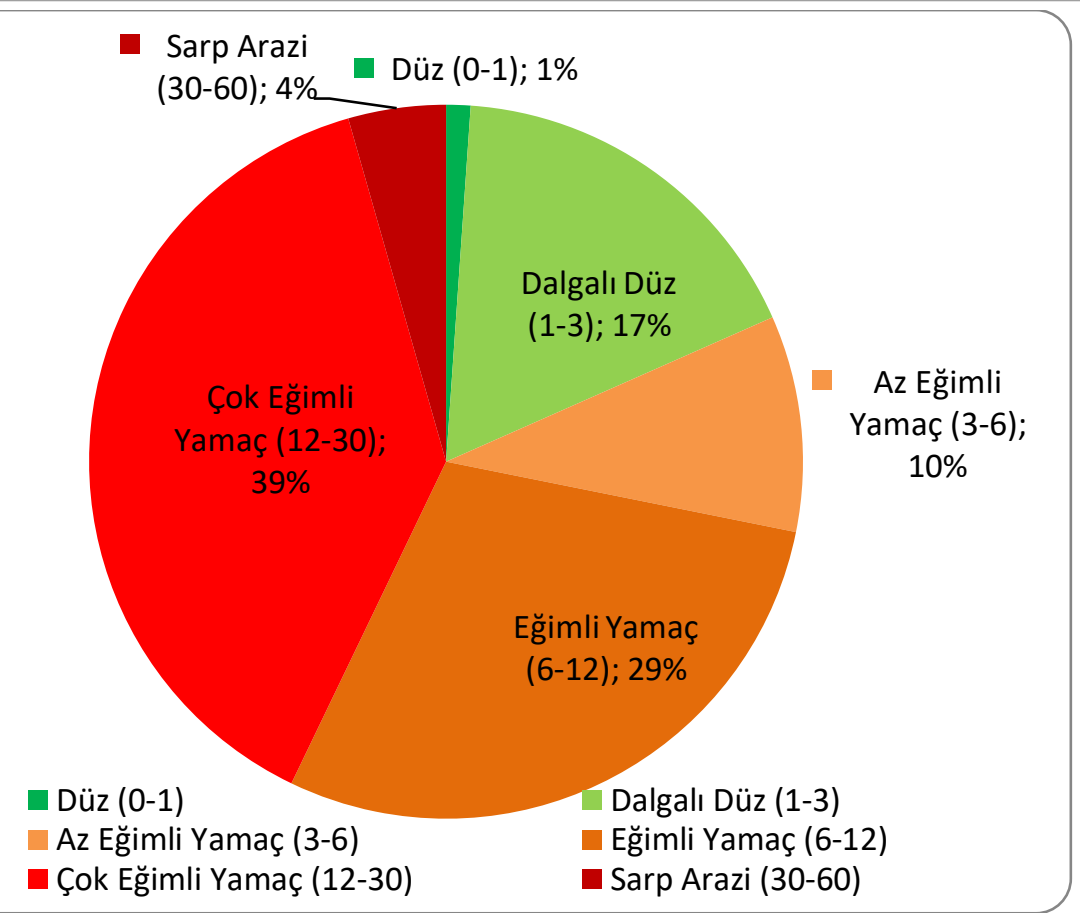

Şekil 11. Maymun Dağı Üzerinde Eğim Değerlerinin Oransal Dağılımı

Acıgöl civarında 850 m'den başlayarak en yüksek yeri Domuz Tepe'de 1689 m'ye ulaşan Maymun Dağı üzerinde çok kısa mesafede 840 m'lik yükselti farkı bulunmaktadır. Genel uzanış olarak doğu-batı (nispeten güneydoğu-kuzeybatı) istikametinde uzanış göstermektedir. Bak1 oranlarının dağılışınada doğal olarak en düşük miktarı düz alanlar $(0,32)$ oluşturmaktadır. Buna karş11ık en yüksek orana ise güney (\%17) ve güneydoğu (\%16) yamaçlar sahiptir. Bunları doğuya bakan yamaçlar (\%14) takip eder (Şekil 12 ve 14). Bu durum Maymun Dağı üzerindeki tektonik uzanışlar ve tektonizmanın gençliği ile paralellik arz etmektedir. Maymun Dağı üzerinde yön olarak en düşük orana batı $(\% 8)$ ve kuzeybatı $(\% 10)$ yamaçlar sahiptir. Bunu güneybatı yamaçlar $(\% 11)$ takip eder. Dağın kuzey (\%12) ve kuzeydoğu (\%12) yamaçları eşit oranda yamaca sahiptir. Genel olarak Oligosen yaşlı tabakalı konglomeralardan oluşan Maymun Dağı'nda kuzeydoğuya dalımlı monoklinal bir yapı özelliği görülmekte olup, bakı yüzeyleri de bu uzanışla uyumlu bir durum arz etmektedir. 


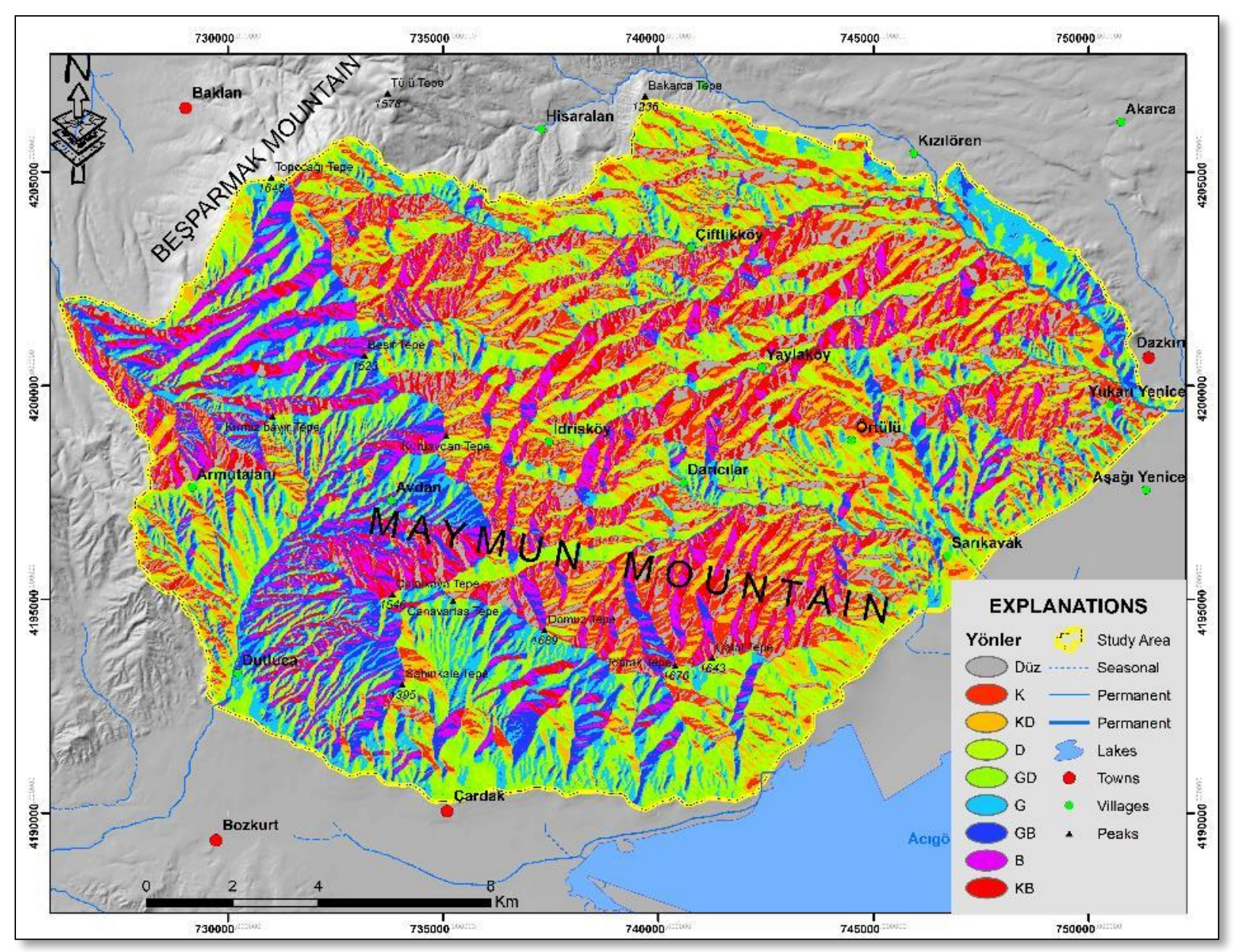

Şekil 12. Maymun Dağının Bakı Haritası

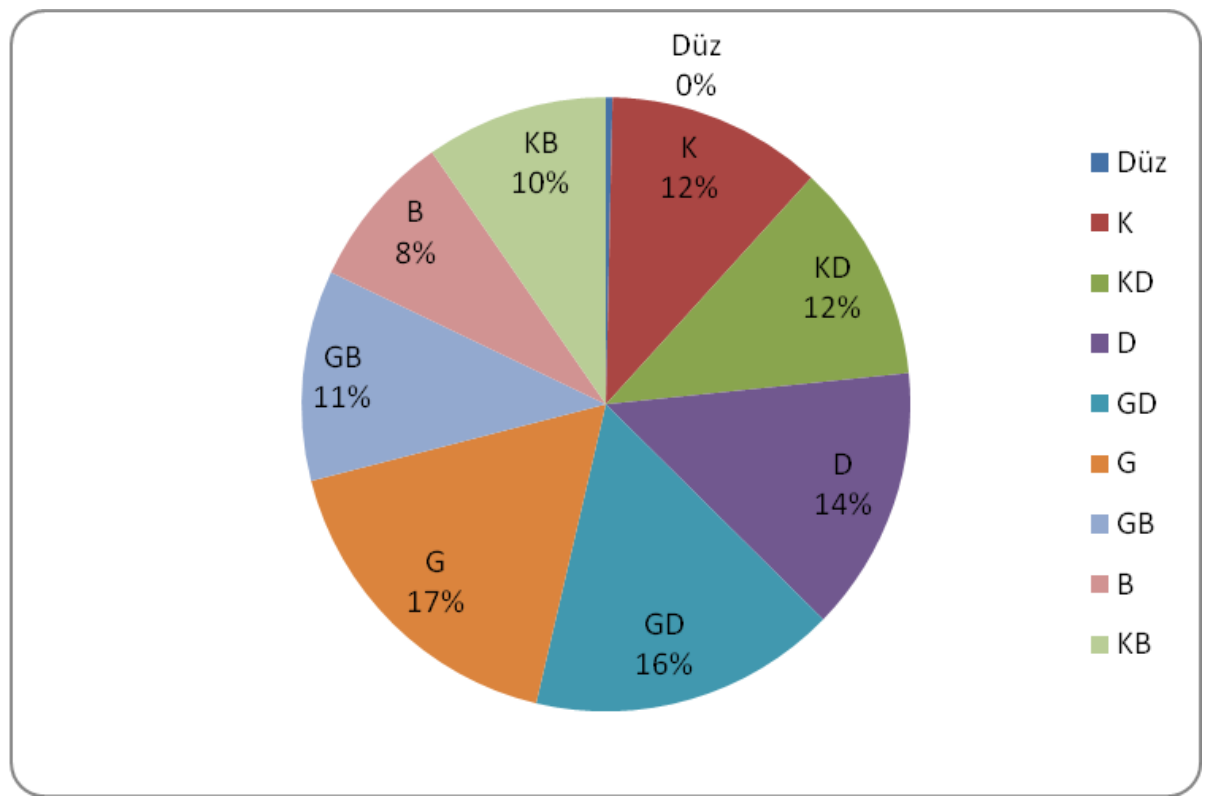

Şekil 13. Maymun Dağı Üzerinde Bakı Değerlerinin Oransal Dağılımı 


\section{Jeomorfolojik Gelişim}

Maymun Dağının bulunduğu alan ve çevresi Triyas-Kretase temel arazisi üzerinde EosenOligosen döneminde sı̆̆ denizel bir ortam özelliği göstermekteydi. Bu dönemlerde çevreden gelen malzemeler yatay konumda depolanmışlardır. Bu dönemler içerisindeki farklı zaman aralığında iri unsurlu malzemeler, bazı dönemlerde ise ince unsurlu malzemeler depolanarak, daha sonra ki dönemlerde bu alan litolojik unsurları kendi içerisinde farklılık arz eden tabakalı bir durum halinde görülmektedir. Acıgöl Grabeni, Güneybatı Anadolu'nun günümüzdeki konumunu almasında etkili olan sıkışma ve genişleme rejimine bağl1, tektonik hareketler sonucu gelişmiş yarı simetrik bir grabendir (Şekil 14). Geç Miyosen süresince Neotektonik dönem, önceki sıkışmaların aksine bir genişleme rejimiyle açıklanmaktadır (Seyitoğlu vd., 1992; Seyitoğlu ve Işık, 2015). Batı Anadolu'da Oligosen dönemindeki karasallaşmayla beraber gelişen sıkışma yerini günümüzdeki KD-GB grabenlerin oluşumuna neden olan KB-GD yönündeki genişleme tektoniğine bırakmıştır. Bu genişleme süreci günümüze kadar devam etmiştir. İnceleme alanında bu dönemi yansıtan en belirgin yapısal unsurlar, Acıgöl Grabenini sınırlayan KD-GB gidişli düşey atımlı "Maymundağı Fayı (Çardak Fayı)" ile grabenin güneyindeki sol yönlü bir bileşene sahip "Acıgöl Fayı"dır. Erken Tortoniyen'de GD yönünde çökerek Acıgöl çöküntüsünü oluşturan bu faylar, basamak faylar oluşturarak günümüze kadar etkinliğini sürdürmüştür. Acıgöl Fayı'nın gelişimiyle yarı graben özelliği kazanan Acıgöl grabeni, daha sonra gelişen Maymundağı Fayı ile grabenin kuzey kenarını da hareketlendirmiştir (Tagliasacchi ve Yağmurlu, 2019). Gölsel fasiyes Pliyosende devam etmiştir. Pliyosen sonlarında Ege Bölgesi'nde açılma tipi tektonizmanın sonucunda horst graben sistemleri kurulurken bu alan Acıgöl fayının etkisiyle kuzeye doğru çarpılarak yükselmiştir (Şekil 14; 15).

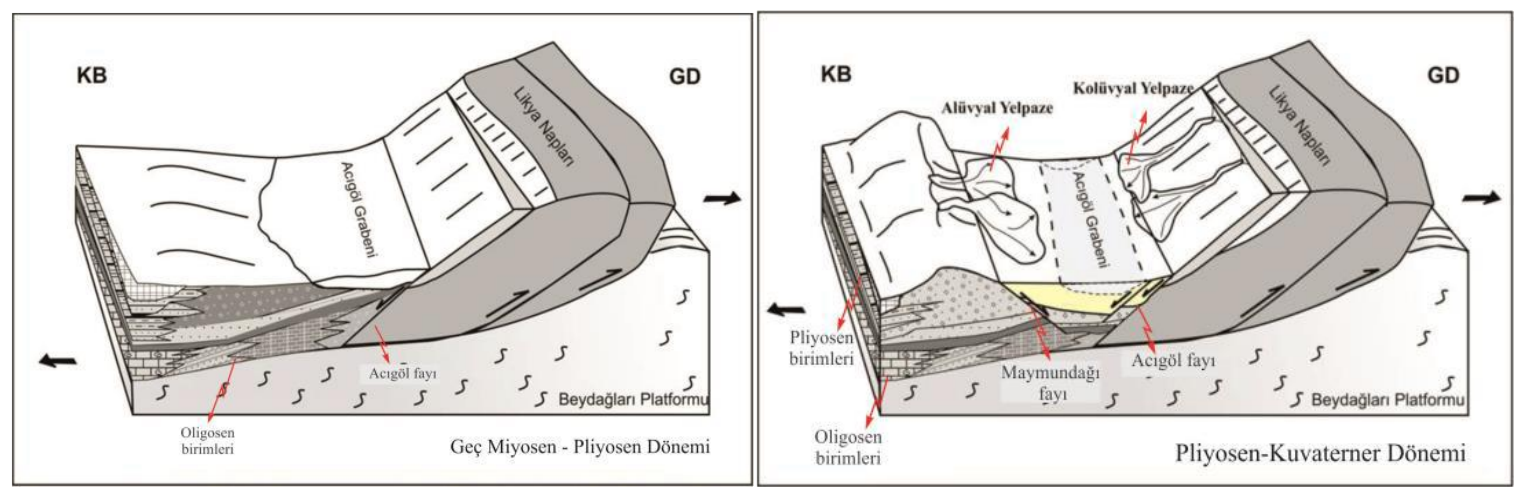

Şekil 14. İnceleme alanının Geç Miyosen-Pliyosen ve Pliyosen-Kuvaterner dönemlerini gösteren blok diyagramları (Tagliasacchi ve Yağmurlu, 2019'dan).

Kuzeybatıda ve kuzeyde Baklan-Dinar grabeni oluşurken güneyde ve güneydoğuda Acıgöl grabeni meydana gelmiş, orta alanda ise Maymundağ-Beşparmak horstu oluşmuştur. Bu yükselim Pliyosen sonlarında önce kuzeyde başlamış Baklan-Çivril Grabeni oluşmuş saha güneye eğimli bir pozisyon almıştır (Ege ve diğ. 2019). Bu esnada Beşparmak Dağları horstu ortaya çıkmıştır. Daha sonra muhtemelen Pleyistosen başlarında Acıgöl Grabeninin kuzeyini oluşturan fayların normal fay karakterinde kırılmasıyla Maymun Dağının yükselimi gerçekleşmiştir. Günümüzde de Maymun Dağı'nı çevreleyen faylardan en aktif olanları güneydoğu ve doğu kesimde yer alanlarıdır. Bu fayların devamları Dinar'a doğru devam etmekte olup 1 Ekim 1995 Dinar Depremi (6,1 büyüklügünde) ve 8 Ağustos 2019 Çardak Depremi (6,5 büyüklügünde) bu aktifliği gösteren en önemli belirteçlerdendir. 


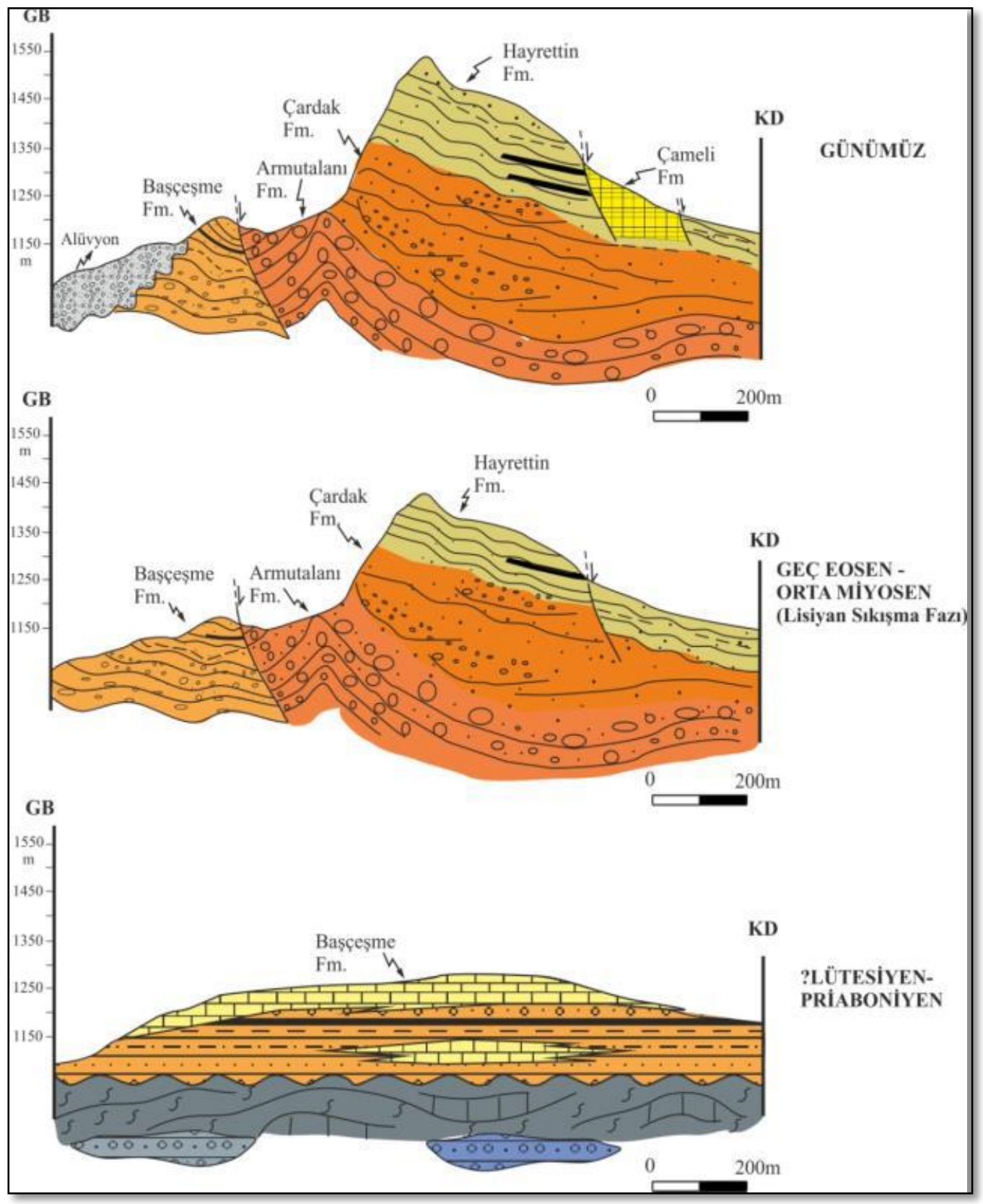

Şekil 15. İnceleme alanı ve çevresindeki Paleojen ve Neojen birimlerin Eosen'den günümüze tektono-sedimanter gelişimi (Tagliasacchi ve Yağmurlu, 2019'dan).

\section{Sonuç ve Öneriler}

Maymun Dağı Acıgöl Grabeninin kuzeyinde $282 \mathrm{~km}^{2}$ 'lik alanı ile kuzeybatıda Baklan-Çivril Grabenleri arasında önemli bir kabartı şeklinde olup, horst alanına karşılık gelmektedir. Tamamen Oligosen yaşlı konglomeralardan müteşekkil olan dağın oluşumu Pliyosen sonu Kuvaterner başındadır.

Maymun Dağı üzerinde morfometrik indislerden bazıları uygulanmış, ortaya çıkan kantitatif veriler ile dağın morfolojik özellikleri ve jeomorfolojik gelişimi açıklanmaya çalışılmıştır. Smf 
verilerine göre dağın KB kesimi çok daha önce oluşmuş Baklan Grabenine karşılık gelirken, G ve GD kesimi çok daha yeni oluşmuş Acıgöl Grabenine karşılık gelmektedir.

İnceleme alanında hakim olan drenaj tipi dantritik drenaj olmakla beraber aktif faylanmaya bağlı olarak bazı kısımlarda kancalı drenaj özelliği de görülmektedir. Bu durumun ortaya çıkmasında tektonizmanın da etkisi vardır.

Maymun Dağının hipsometrik integrali 0,49 olarak hesaplanmıştır. Her ne kadar bu durum dağın olgunluk aşamasında olduğunu gösterse de dağı oluşturan konglomeraların aşınıma karş1 dirençsiz olması nedeniyle sahanın çok hızlı bir şekilde aşındırıldığını ve bu sonucun çıtığını söyleyebiliriz. Oysaki dağı oluşturan akarsu havzalarından güney ve güneydoğuda yer alan havzaların çok genç çıkması, morfolojik gözlemler ve aktif tektonik özellikler Maymun Dağının henüz oluşma aşamasında genç bir dağlık kütle olduğunu göstermektedir.

Maymun Dağ 1 üzerinde dört yönden Smf değeri hesaplanmıştır. Buna göre dağın kuzeydoğu kesimi $(\mathrm{Smf}=3,35)$ tektonik aktivitenin en az olduğu yere karşılık gelirken dağın güney $(\mathrm{Smf}=1,2)$ ve güneydoğu kesimleri $(\mathrm{Smf}=1,17)$ tektonik aktivitenin en yüksek olduğu alanlara karşıllık gelmektedir. Beşparmak Dağı'nın batısında $(\mathrm{Smf}=2,9)$ ise daha eski tektonizmayı göstermekte olup artık flüvyal süreçlerin baskın hale geldiği görülmektedir. Buna göre dağın kuzeybatı yamacı ilk olarak oluşmuştur. Bu durum Oligosende ortaya çıkan KD-GB doğrultudaki paleo-graben oluşumu ile örtüşmektedir. Daha sonra güneyi ve güneydoğu kesim oluşurken Dazkırı merkez ve doğu kesim nispeten hareketsiz çekirdek nokta görevini görmektedir.

Maymun Dağı üzerinde yer alan yaklaşık 10 havza üzerinde çeşitli noktalardan Vf hesaplaması yapılmıştır. Buna göre çoğunlukla akarsuların yukarı (memba) ve orta kısımları düşük Vf değerleri ile daha çok aşınım sürecinde olduklarını gösterirken, aşağı çığırlar yüksek Vf değerleri ile birikim safhalarını göstermektedir.

Maymun Dağı üzerinde bulunan havzalardan özellikle kuzey-kuzeydoğudaki havzalarda yüksek derecede asimetri söz konusudur. Buna karş1lk aktif tektoniğin çok etkin olduğu güney kesimde düşük derecede de olsa asimetriklik görülür.

Maymun Dağının güney ve güneydoğusunda yüksek üçgen yüzeyler (façetalar) ve bunların önünde oldukça küçük birikinti konilerinin yer alması aktif tektoniği göstermektedir.

Maymun Dağı üzerinde \%80'lik bir alan eğimli ve yüksek eğimli sahalara karşılık gelirken \%18'lik bir alan düz ve dalgalı düzlük sahaya karşılık gelmektedir. Bu durumda Maymun Dağının oldukça genç oluşumlu bir sahaya karş1lık geldiğini göstermektedir. Bak1 olarak ise en yüksek bak1 değerleri en genç olan güney $(\% 17)$ ve güneydoğu (\%16) yamaçlara karş1l1k gelirken en düşük bak1 değerine batı (\%8) ve kuzeybatı (\%10) kesime karşıl1k gelmektedir.

Maymun Dağının jeomorfolojik gelişimi incelendiğinde dağın kuzeydoğusunda yer alan Dazkırı ve çevresi nispeten sabit olup Oligosenden Pliyosen sonlarına kadar depolanma alanı konumundadır. Pliyosen sonlarında önce kuzeydeki Baklan-Çivril Grabeni oluşmuştur. Böylece Oligosen yaşlı tortullar güneydeki Acıgöl Grabenine doğru meyillenmiştir. Acıgöl Grabeni bu dönemde yarı graben özelliğindedir. Daha sonra Kuvaterner başlarında Acıgöl Grabeninin kuzey kesimi kırılarak (Maymundağ-Çardak fayı) kuzeye doğru meyilli Maymun Dağı ortaya çıkmıştır.

Günümüzde dağın güney ve güneydoğu kesimindeki Acıgöl fayının aktivitesi halen devam etmektedir. Bu nedenle bu alanlarda en genç fay façetalarına rastlanır. 8 Ağustos 2019 tarihinde meydana gelen 5,8 büyüklüğündeki Çardak depremi esnasında bu noktadan çok büyük gaz ve toz bulutu çıkışı olduğu yöre halkı tarafından ifade edilmiştir. Bu nedenle Maymun Dağının, güney, güneydoğu kesimi ve yakın çevresinin yüksek derecede deprem riski ihtiva ettiğini söylemek mümkündür. 
İnceleme alanı tektonik açıdan aktif olması ve depremsellik riskinin yüksek olması bu alandaki insanların bilinçlendirilmesi gerektiği de göstermektedir. Özellikle meskenler depreme dayanıklı bir şekilde inşa edilmelidir. 8 Ağustos 2019 tarihinde az hasar görmüş yapılar da tespit edilerek halkın kullanımına son verilmeli, olası depremler için önlemler alınmalıdır.

\section{Teşekkür}

Yazarlar bu çalışmada arazi incelemelerine katılan Uşak Üniversitesi, Coğrafya Bölüm öğrencilerinden Şeyma AYHAN ve Atabek AKNAZAROV'a teşekkür ederler.

\section{Kaynakça}

Avc1, V. ve Günek, H., (2015). Uludere Havzası'nın (Bingöl) Jeomorfolojik Özelliklerinin Belirlenmesinde Morfometrik Analizlerin Kullanımı, Adıyaman Üniversitesi, Sosyal Bilimler Enstitüsü Dergisi, 21, 745-766. https://doi.org/10.14520/adyusbd.39800

Avc1, V. ve Kıranşan, K., (2017). Darköprü Deresi Havzası'nda (Bingöl) tektonik etkinin morfometrik analizlerle belirlenmesi, Uluslararası Sosyal Araştırmalar Dergisi, 10 (48), 270-284. https://doi.org/10.17719/jisr.2017.1499

Avc1, V., ve Sunkar, M., (2017). Jeomorfik Indislerle Varto Havzası'nda (Muş) Tektonik Aktivitenin Belirlenmesi. Türk Coğrafya Kurumu 75. Kuruluş Yılı Kongresi Tam Metin Bildiriler Kitab1 (s. 730 - 742). Ankara: Türk Coğrafya Kurumu.

Bahadır, M. ve Özdemir, M.A.(2011). Acıgöl Havzası'nın Sayısal Topoğrafik Analiz Yöntemleri İle Morfometrik Jeomorfolojisi. Uluslararası Sosyal Araştırmalar Dergisi Journal of International Social Research, Cilt:4 Say1:18

Biswas, S.,Sudhakar, S., Desai, V.R., (1999). Prioritisation of Subwatersheds Based on Morphometric Analysis of DrainageBasin: A Remote Sensingand GIS Approach, Journal of the Indian Society of Remote Sensing, Vol. 27, No.3, p. 155-166. https://doi.org/10.1007/bf02991569

Bull, B. W., (1977). Tectonic geomorphology of the Mojave Desert, U.S. Geological Survey Contact Report 14-08-001-G-394.

Bull, W.B., (1978). Geomorphic Tectonic Activity Classes of the South front of the San Gabriel Mountains, California. U.S.

Bull W. B., (2007). Tectonic Geomorphology of Mountains: a new approach to paleoseismology (p. 328). Wiley-Blackwell, Oxford

Burbank, D.W., Anderson, R.S., (2012). Tectonic Geomorphology. second ed. Wiley-Blackwell (454 pp.).

Ceylan, M.A., (1998). Baklan-Çivril Havzası ve Yakın Çevresinin Hidrojeomorfolojik Etüdü, , Marmara Üniveritesi/Sosyal Bilimler Enstitüsü, (Yayımlanmamış Doktora Tezi) 260 p.. İstanbul

Cox, R.T., (1994). Analysis of Drainage-basinSymmetry as a Rapid Technique to Identify Areas of Possible Quaternary Tilt-block Tectonics: an Example from the Mississippi Embayment, Geol. Soc. Am. Bull., 106, 571-581. https://doi.org/10.1130/00167606(1994)106<0571:aodbsa>2.3.co;2

Cürebal, İ., (2004). Madra Çayı'nın Hidrografik Özelliklerine Sayısal Yaklaşım. Balıkesir Üniversitesi, Sosyal Bilimler Enstitüsü Dergisi, Say1:11, 11-24. 
Cürebal, İ. ve Erginal, A.E., (2007). Mıhlı Çayı Havzası'nın Jeomorfolojik Özelliklerinin Jeomorfik İndislerle Analizi, Elektronik Sosyal Bilimler Dergisi, 19, 126-135.

Demoulin, A., (2011). Basin and River Profile Morphometry: A New Index With A High PotentialforRelativeDating of Tectoni Cup Lift, Geomorphology, 126, 97-107. https://doi.org/10.1016/j.geomorph.2010.10.033

Ege, İ., Polat, S.ve İzmirli, E., (2019). Özdemirci (Çivril - Denizli) Havzası'nın Morfotektonik Özelliklerinin Cbs İle Belirlenmesi, Mustafa Kemal Üniversitesi, Sosyal Bilimler Enstitüsü Dergisi, 16(44), 141-167.

Efe, R., (1994). Biga Yarımadasında Neotektoniğin Jeomorfolojik İzleri. Türk Coğrafya Dergisi, S. 29: 209-242.

Erginal, A.E. ve Cürebal, İ., (2007). Soldere Havzasının jeomorfolojik özelliklerine morfometrik yaklaşım: jeomorfik indisler ile bir uygulama, Selçuk Üniversitesi Sosyal Bilimler Enstitüsü Dergisi, 17, 203-210.

Fural, Ş. (2018). Acısu Çayı'nın (Serik-Antalya) Drenaj Özelliklerinin Morfometrik Analizi, JassStudies-TheJournal of Academic Social Science Studies, Number: 72 Autumn III 2018, p. 541-556. https://doi.org/10.9761/jasss 7914

Geçen, R. ve Ölmez, İ., (2017). Beyazçay Havza'sının (Hatay) Jeomorfometrik Analizler İle Değerlendirilmesi, UJES-2017 Bidiriler Kitab1, 212-221

Göktaş, F., Çakmakoğlu, A., Tarı, E., Sütçü, Y.E., Sarıkaya, H., (1989). Çivril-Çardak Arasının Jeolojisi. MTA Rapor, No:318.

Gürbüz, A., Boyraz, S. and M. Tariq Ismael, T., (2012). Plio-Quaternary Development of The Baklan-Dinar Graben: Implicationsfor Cross-Graben Formation in SW Turkey, International Geology Review, Vol. 54, No. 1, January, 33-50, https://doi.org/10.1080/00206814.2010.496543

Hack, J. T., (1973). Stream-Profile Analysis andStream-Gradient Index", U.S. Geological Survey Journal of Research. 1, 421- 429.

Harlin, J. M., (1978). Statistical moments of the hypsometric curve and itsdensity function, Journal of the International Associationfor Mathematical Geology, 10 (1), 59-72. https://doi.org/10.1007/bf01033300

İzmirli, E. ve Ege, İ., (2019). Gökpınar Çayı Havzasının Jeomorfometrik İndisler İle İncelenmesi, Gelecek Vizyonlar Dergisi (fvj: Future Visions Journal) 3(3): 2019, 41-57 https://doi.org/10.29345/futvis.81

Karataş, A., (2014). Karasu Çayı Havzasının Hidrografik Planlaması, İstanbul Üniversitesi/Sosyal Bilimler Enstitüsü, Coğrafya Anabilim Dalı (Yayımlanmamış Doktora Tezi), İstanbul

Keller, E.A., (1986). Investigation of Active Tectonics: Use of Surficial Earth Processes, In: Washington, D.C. (Ed.), Panel on Active Tectonics. National Academy Press, 136-147.

Keller, E.A. ve Pinter, N., (2002). Active Tectonics, Earthquakes, Uplift and Landscape, Second edition. Prentice Hall, Upper Saddle River

Koçyiğit, A., (1984). Güneybatı Türkiye ve Yakın Dolayında Leva İçi Yeni Tektonik Gelişim, Türkiye Jeoloji Kurumu Bülteni, 27 (1), 1-15

Koçyiğit, A., Ünay, E., Saraç, G., 2000. Episodic graben formation and extensional neotectonic regime in west Central Anatolia and the Isparta Angle: a case study in the Akşehir-Afyon 
Graben, Turkey. Geol. Soc. London, Spec. Pbl. $173 . \quad$ pp. 405-421. https://doi.org/10.1144/gsl.sp.2000.173.01.19

Koçyiğit, A., 2005. The Denizli Graben-Horst System and the Eastern Limit of Western Anatolian Continental Extension: Basin Fill, Structure, Deformational Mode, Throw Amount and Episodic Evolutionary History, SW Turkey. Geodinamica Acta, 18/3-4, pp.167-208. https://doi.org/10.3166/ga.18.167-208

Köle, M.M., (2016). Devrez Çayı vadisinin tektonik özelliklerinin morfometrik indisler ile araştırılması, Istanbul Üniversitesi, Edebiyat Fakültesi Coğrafya Dergisi, 33, 21-36. http://www.journals.istanbul.edu.tr/iucografya

Mayer, L., (1990). Introduction to Quantitative Geomorphology, PrenticeHall, New Jersey.

Melton, M.A., (1957). An analysis of the relation amongelements of climate, surface properties and geomorphology, Tch. Rep. No. 11, Department of Geology, Columbia University, New York.

Moglen, G.E.;Brass, R.L., (1995). Theeffect of spatial heterogeneities on geomorphic expression in a model of basin evolution, Water Resour. Res.,31, 2613-2623. https://doi.org/10.1029/95wr02036

Özdemir, H., (2007). Havran Çayı Havzasının (Balıkesir) CBS ve Uzaktan Algılama Yöntemleriyle Taşkın ve Heyelan Risk Analizi. Yayınlanmamış doktora tezi, İstanbul Üniversitesi/Sosyal Bilimler Enstitüsü, İstanbul.

Özdemir, H., (2011). Havza Morfometrisi ve Taşkınlar, Fiziki Coğrafya Araştırmaları; Sistematik ve Bölgesel, Türk Coğrafya Kurumu Yayınları, No:5, 507-526,

Öztürk, B., (2008). Biga Yarımadasında Asimetrik Havza Gelişimi ve Yapı İlişkisine Bir Örnek: Yapıldak Dere Havzası. Çanakkale Araştırmaları Türk Yıllı̆̆ı Dergisi, S. 6-7: 133-149

Öztürk, B. ve Erginal, A.E., (2008). Bayramdere Havzasında (Biga Yarımadası- Çanakkale) Havza Gelişiminin Morfometrik Analizler ve Jeomorfolojik İndislerle İncelenmesi, Türk Coğrafya Dergisi, 50, 61-68.

Pike, R.J. ve Wilson, S.E., (1971). Elevation Relief Ratio, Hypsometric Integral and Geomorphic Area-Altitude Analysis, Geol. Soc.Am. Bull., 62, 1079-1084. https://doi.org/10.1130/00167606(1971)82[1079:erhiag]2.0.co;2

Philippson, A., (1915). ErgaenzungsheftezuPetermannsMitteilungen, (Nr. 167, 1910; 172, 1911; $177,1913 ; 180,1914 ; 183,1915)$ Berlin

Price, P. C., Scott, B., 1994. Fault-block Rotations at the Edge of A Zone of Continental Extension, Southwest Turkey, J. Struct. Geology 16, 381-392. https://doi.org/10.1016/0191-8141(94)90042-6

Reddy, G.P.O.,Maji, A.K., Gajbhiye, K.S., (2004). Draina gemorphometry and itsinfluence on landformcharacteristics in basalticterrain, centralIndia - a remotesensingand GIS approach. Int J Appl. Observ. Geoinf. 6:1-16.

Sarp, G., Geçen, R., Toprak V., Düzgün, Ş., (2011). Morphotectonic Properties of Yenicaga Basin Area in Turkey, 34th International Symposium on Remote Sensing of Environment April 1015, 2011 Sydney, AUSTRALIA

Seyitoğlu, G., Scott, B.C., Rundle, C.C. (1992). Timing of Cenozoic extensional tectonics in west Turkey. Journal of the Geological Society, London, 149, 533-538. https://doi.org/10.1144/gsjgs.149.4.0533 
Seyitoğlu, G. ve Işı1k, V., (2015). Late cenozoic extensional tectonics in western anatolia: Exhumation of the menderes core complex and formation of related basins, Bulletin of The Mineral Research and Exploration · December 2015 MTA Dergisi (2015) 151: 49-109 https://doi.org/10.19111/bmre.49951

Schumm, S.A., (1956). Evolution of drainagesystemsandslopes in badlands at PerthAmboy, New Jersey. Geol. Soc. Am. Bul. 67, 597-646.

Simoud, E.;Karagkouni, V.; Papantoniou, G. AndNomikou, P. (2013). Morphotectonicanalysis of KozaniBasin (Western Macedonia, Greece), Bulletin of the Geological Society of Greece, XLVII (2), 657-666. https://doi.org/10.12681/bgsg.11099

Sözbilir, H. 2005. Oligocene-Miocene extension in the Lycian orogen: evidence from the Lycian molasse basin, SW Turkey. Geodinamica Acta 18, 255-282. https://doi.org/10.3166/ga.18.255-282

Strahler, A. N., (1952), Hypsometric (area-altitude) Analysis of Erosional Topography, Geological Society of America Bulletin (63), 1117-1142. https://doi.org/10.1130/00167606(1952)63[1117:haaoet]2.0.co;2

Şahbaz, A., Görmüş, S. 1992. Çardak (Denizli) Kuzeyindeki Eosen-Oligosen Yaşlı Konglomeraların Stratigrafik ve Sedimantolojik Incelemesi. Türkiye 9. Petrol Kongresi ve Sergisi, 62-74s., Ankara.

Şenel, M. 1997. Denizli-J9, 1/100.000 Ölçekli Jeoloji Haritası ve Açıklamalı Kitapçı̆̆ı. MTA Yayınları, 18s., Ankara.

Tagliasacchi, E ve Yağmurlu, F. (2019) Acıgöl Grabeni Kuzeyindeki Pliyo-Kuvaterner Yaşlı Karasal Çökellerin Fasiyes Özellikleri ve Bölgenin Paleoortamsal Gelişimi, GB-Türkiye, Süleyman Demirel Üniversitesi, Fen Bilimleri Enstitüsü Dergisi, Cilt 23, Say1 2, 440-451, 2019 https://doi.org/10.19113/sdufenbed.462302

Toker, E. 2008. Acıgöl-Çardak (Denizli) Grabeninin Kuzeyindeki Tersiyer Çökellerinin TektonoSedimanter Gelişiminin İncelenmesi, Doktora Tezi, 242, Isparta.

Topal, S., (2012). Denizli Havzasındaki Fayların Tektonik Jeomorfolojisi (GB Türkiye), Pamukkale Üniversitesi/Fen Bilimleri Enstitüsü, Yayımlanmamış doktora tezi, Denizli.

Topal, S., (2018). Quantitative analysis of relative tectonic activity in the Acıgöl fault, SW Arabian Journal of Geosciences, 11:198, https://doi.org/10.1007/s12517-018-3545-z

Topuz, M. ve Karabulut, M. (2016). Limonlu ve Alata Havzalarının (Mersin-Erdemli) jeomorfometrik analizi, Turkish Studies, $11 \quad$ (2), 1231-1250. https://doi.org/10.7827/turkishstudies.9165

Turoğlu, H., (1997). İyidere Havzasının Hidrografik Özelliklerine Sayısal Yaklaşım, Türk Coğrafya Dergisi, 32, 355-364.

Uzun, M., (2014). Lale Dere (Yalova) Havzası'nın jeomorfolojik özelliklerinin jeomorfometrik analizlerle incelenmesi, Route Educational and Social Science Journal, 1(3), 72-88. https://doi.org/10.17121/ressjournal.91

Western, A. W., Finlayson, B. L., McMahon, T. and A.; O’Neil, I. C. (1997). A Method for Characterizing Longitudinal Irregularity in River Channels, Geomorphology, 21, 39- 51. https://doi.org/10.1016/s0169-555x(97)00023-8 
Maymun Dağı(Çardak-Denizli/Dazkırı-Afyonkarahisar)'nın Morfotektonik Özelliklerinin... 307

Yıldırım, A.ve Karadoğan, S. (2011). Raman Dağları Güneyinde (Dicle Vadisi) Morfometrik ve Morfotektonik Analizler, Dicle Üniv. Ziya Gökalp Eğitim Fakültesi Dergisi, 16, 154-166. https://doi.org/10.14582/duzgef.674

Zeybek, H. İ. (2010). Turhal Ovası (Doğal Ortam Özellikleri). İstanbul: Çantay Yayınları

Zorer H. ve Tonbul, S. (2019). Başkale Havzası'nda Havza Gelişiminin Jeomorfometrik Analizlerle İncelenmesi, Firat Üniversitesi Sosyal Bilimler Dergisi, Vol. 29, No. 2, Pp. 19-38, Jul. 2019. https://doi.org/10.18069/firatsbed.536045 